\title{
Büiưik Veriye İletişimsel Yaklaşımlar: Web of Science Yayınlarının Sistematik Bir Analizi
}

\section{Communicative Approaches to Big Data: A Systematic Analysis of Web of Science Publications}

\author{
Zafer KIYAN $^{1}$, Nurcan TÖRENLİं ${ }^{2}$
}

${ }^{1}$ Res. Asst. Dr., Ankara University, Faculty of Communication, Ankara, Turkey 2Prof. Dr., Ankara University, Faculty of Communication, Ankara, Turkey

ORCID: Z.K. 0000-0002-7318-5419; N.T. 0000-0001-8520-3138

\section{Sorumlu yazar/Corresponding author:} Zafer Kıyan,

Ankara Üniversitesi, İletişim Fakültesi, Ankara, Türkiye

E-posta/E-mail: zkiyan@media.ankara.edu.t

Geliş tarihi/Received: 10.01 .2020 Revizyon talebi/Revision Requested: 14.02.2020

Son revizyon teslimi/Last revision received: 19.03 .2020

Kabul tarihi/Accepted: 10.05.2020

Atıf/Citation: Kiyan, Z., \& Torenli, N. (2020) Büyük veriye iletişimsel yaklaşımlar: web of science yayınlarının sistematik bir analizi. Connectist: Istanbul University Journal of Communication Sciences, 58, 241-272 https://doi.org/10.26650/CONNECTIST2020-0002
Öz

Literatür incelemesi niteliğindeki bu çalışma büyük veriye iletişim perspektifinden yaklaşan 62 makaleyi analiz etmektedir. Çalışma bu haliyle konuya ilgi duyan araştırmacılara büyük veri etrafında dönen tartışmaları, büyük veri analizi için tercih edilen kuramsal yaklaşımları ve kullanılan yöntemleri bir arada görebilme olanağı tanımaktadır. Çalışma kapsamına dâhil edilen makaleler niteliksel içerik analiz tekniği kullanılarak analiz edilmiştir. Bu yöntem, sistematik kodlamaya ve nitel yoruma olanak tanıdığı için literatür çalışmaları için oldukça elverişlidir. Analiz, incelemeye konu olan makalelerin iki ayrı gruba ayrıldıklarını ortaya koymuştur. Buna göre ilk gruptaki 45 makale doğrudan büyük veriye odaklanıp onu sorunsallaştırırken; ikinci gruptaki 17 makale büyük veriyi dolaylı olarak ele almakta ve iletişim eksenli bir konuyu ya da sorunu büyük bir veri kümesiyle analiz etmektedir. Bu ayrışma hem büyük veri olgusunun iletişim alanına özgü çalışmalarda yeni oluşundan hem de araştırmacıların karşısına çıkan çok sayıda araçsal ve bilişsel zorluklardan, sorunlardan kaynaklanmaktadır. Bu ayrışma elde edilen bulguları da farklılaştırmıştır. Çalışma bu haliyle odaklandığı konu ve ulaştığı sonuçlar açısından Türkçe literatürde önemli bir boşluğu dolduracak niteliktedir.

Anahtar Kelimeler: Büyük veri, iletişim çalışmaları, sosyal medya, veri analizi, etik

\section{ABSTRACT}

This study was designed as a literature review analysis of 62 journal articles that approach big data from a communicative perspective. The study allows researchers interested in the subject to gain an overview of the discussions revolving around big data, as well as the preferred theoretical approaches for big data analysis and the methodologies used. The articles included in the study were analyzed using qualitative content analysis. This method is suitable for literature studies since it allows for systematic coding and qualitative 
interpretations. The analysis revealed that the articles under examination were divided into two groups with 45 focused directly on big data and 17 indirectly analyzing big data. The articles in the first group generally problematized big data, whereas those in the second group analyzed a communication-based topic or problem using a large data set. This differentiation arises both from big data phenomenon being new in the field of communication and from numerous instrumental and cognitive difficulties and problems that researchers face in this field. This study fills an important gap in Turkish literature on the topic both in terms of its focus and conclusions drawn.

Keywords: Big data, communication studies, social media, data analysis, ethics

\section{EXTENDED ABSTRACT}

This study analyzes journal articles approaching big data from a communicative perspective, which has recently received wide interest in the communication field (Couldry, \& Turow, 2014). The analyzed articles were selected from journals indexed in the Web of Science database. Within this scope, 120 articles were screened from the related database, and those written in English about the subject of big data were obtained. A preliminary reading of the abstract and introduction sections of articles was undertaken, and 70 articles found suitable for analysis were included in the study. During the detailed reading of the 70 articles, eight were excluded from the study since they were not related to the topic, and thus the final sample consisted of 62 articles. These articles were analyzed using the qualitative content analysis technique.

As a result of the analysis, general and specific findings were obtained. The first general finding concerned the differences and diversity in relation to the approach to big data. The first initiative for the analysis of big data was the 2012 publication of Boyd and Crawford, which was a reference guide. In that work, the authors provided a comprehensive and critical evaluation of big data from different perspectives. From 2012 to the present day, big data-driven studies have increased in number and gained diversity in terms of the subjects investigated. The second general finding was related to basic concepts that defined the articles. In this regard, the articles used terms, such as social media, data analysis, and ethics along with big data. These terms offered clues about the areas of focus related to big data. The third and most important general finding was the differentiation in the type of analysis undertaken in the articles, resulting in two separate groups: while 17 articles in the first group indirectly analyzed big data, 45 in the second group directly focused on the subject. More specifically, the articles in the first group analyzed a communication-based issue or problem using a large data set, whereas the second group of articles focused directly on big data and examined it in the context of the hopes, concerns, and fears they cause in today's societies. 
The division of the articles into two groups also led to certain specific findings. For example, almost all the articles in the first group were quantitative studies. These characteristics differentiated them in terms of the analysis of big data. First, the articles in this group focused on different topics of communication, most notably on the role of media in agenda setting, followed by audience research, political communication, and the public sphere. Second, the articles in the same group conducted their analysis using a predominantly theoretical approach, with the Agenda Setting Theory being the most important. Third, they mostly preferred new media platforms, such as Twitter, Facebook, and news web pages to collect data. Lastly, they generally used more than one research method for the data analysis, which were mostly quantitative techniques.

Almost all the articles in the second group belonged to theoretical and conceptual studies. Like the articles in the first group, these qualities differentiated them in terms of their approach to big data. First, the articles in this group interpreted the transformation seen in the field of communication through the use of big data as a paradigm shift. Second, they discussed the results obtained from the analysis of big data in different ways from individual to social levels in the context of a benefit/harm contrast. Third, they highlighted the problems in relation to big data, especially those that were ethical, theoretical, or methodological, as well as commercial, political, cultural, or ideological problems. Lastly, they argued that big data did not mean 'the end of theory'.

When the results are evaluated as a whole, it can be said that communication researchers tend to deal with big data as adopting a relational rather than instrumentalist approach while producing social information. Indeed, the questions raised in the articles; e.g., 'Where does big data come from?' (Hammond, 2017), 'Can quantitative data analysis really help us to understand the society as a whole?' (Kelly, 2019; Leckner, \& Severson, 2019), 'Can human behavior be modeled adopting electronic tracks?' (Fuchs, 2017b), 'Does the fact that we are analyzing data using advanced computer-algorithms mean that we will reach accurate and precise findings about the society?' (Baruh, \& Popescu, 2017; Crawford, Miltner, \& Gray, 2014), 'Despite the great expectations from big data, were not the results quite limited?' (Chan, 2015; Poel, Meyer, \& Schroeder, 2018), and 'When we ignore research ethics, do we not lessen the value of information we produce for the society?' (Halavais, 2015) led us to the idea that communication researchers examined big data not by looking at numbers but by considering the relationships between people. 
Here, what is striking is that communication researchers are forced to choose between their own benefit and social benefit in their efforts to produce information. Communication researchers are in a position to meet the needs of society at the same time as looking out for their own interest. Therefore, they have far more responsibility and work in terms of the analysis and interpretation of big data. People who impose individual benefits on the academic world rather than considering social benefits are those who try to win over communication researchers in order to maximize their personal/limited benefits thus, restricting access to big data for the so-called benefit of society. The way to overcome this is through the persistence of interdisciplinary solidarity of communication researchers, as suggested by Boyd and Crawford (2012). 


\section{GíRiş}

Büyük veri, günümüzde sadece bilgisayar bilimleri alanındaki akademisyenlerin değil bilişim teknolojileri alanındaki şirketlerden başlayarak neredeyse bütün iş dünyasının ve bilgi güvenliği-kamu düzeni meseleleriyle doğrudan ilgisi nedeniyle kaçınılmaz olarak devletlerin' birbirleriyle yarışırcasına 'hasadına' giriştiği (Couldry, \& Turow, 2014) önemli bir olgu haline gelmiştir. Bu duruma koşut olarak büyük verinin ne anlama geldiği araştırmacılar arasında önemli bir tartışma konusu olmuştur. Bazı araştırmacılar (örneğin Kelly, 2019), büyük veriyi büyüklük ('volume'), hız ('velocity') ve çeşitlilik ('variety') başlıkları altında 3V olarak formülleştirerek tanımlamaktadır. Bu formülasyonda büyüklük, ancak bilgisayarlar yoluyla işlenebilecek büyüklükte nicel veri çokluğuna işaret ederken, hız bu nicel çokluğun üretilme ve elde edilme hızına/ süresine denk gelmekte, çeşitlilik ise verinin doğasındaki heterojenliğe, yani farklı türden içeriklere gönderme yapmaktadır.

Büyük verinin nicelik açısından üç temel özelliğinden yola çıkan bu formülasyonun kapsayıcılığı özellikle toplumsal etkileşimde Twitter ve Facebook gibi sosyal medya platformlarının giderek ağırlık kazanmaya başlamasıyla birlikte sınırlı kalmaya başlamıştır. Nitekim bu platformlarda yanıltmaya, tutum ve davranışları yönlendirmeye dönük gerçek dışı içeriklerin dolaşımda olduğu dikkate alınarak $3 \mathrm{~V}$ formülüne bir dördüncüsü (4V) eklenerek, büyük verinin nitel anlamda doğru ve geçerli (verocity) bir veri olması gerekliliğine vurgu yapılmıştır (genel bir tartışma için bkz. Rubin 2017). Kapsamın nitel anlamda genişletilme ihtiyacı doğrultusundaki arayışlarını sürdüren bazı araştırmacılar (Quan-Haase, \& Sloan, 2017) ise büyük verinin sadece nesneler hakkında değil insanlar hakkında toplanan veriler olmasından hareket ederek $4 \mathrm{~V}$ formülasyonuna veri kullanımını da işin içine katacak iki boyut eklemişler ve formülasyonu $6 \mathrm{~V}$ haline getirmişlerdir. $\mathrm{Bu}$ son iki boyut, büyük veriye ilişkin tanımın nicel odaklı çerçevesini genişleterek onu nitel özelliklerle dengelemiştir. Bu boyutlardan ilki (yani'virtue') büyük verinin çeşitli amaçlarla kullanımında etik yönün önemine işaret ederken, diğeri (yani 'value'), büyük verinin insanın içinde yaşadığı gerçek dünyayı algılayışına ve kavrayışına katkı vermesi gerekliliğine dikkat çekmektedir.

Büyük veriye iletişimsel yaklaşımlar söz konusu olduğunda, bu ‘moda' kavramın çağrıştırdığı teknik-teknolojik belirlenimci çerçeveye farklı dozlarda da olsa çok sayıda itirazın yükseldiğini söyleyebiliriz. Büyük verinin sıradan insanlar açısından taşıdığı bilinmezliğe (Qiu, 2015) ya da gizeme (Crawford et al., 2014) yönelen bu itirazlar, temel 
olarak içeriğin (enformasyonun) üretimi ve toplumsal gerçekliğin bilgisinin üretimi arasındaki ayrışma ile bu ayrışmada kuram bilgisinin konumlanışını görmezden gelerek (Halavais, 2015) her türden toplumsal yararı pratik yarara dönüştüren ya da bu yararı sonuç alma adına kutsayan işlevselci-faydacı anlayışlara yöneliktir. Başka bir açıdan bakıldığında, söz konusu itirazlar büyük veriyi sanki kendinden veriliymişçesine pratik yarara endeksleyen meşrulaştırma çabalarıyla bunların üzerini örttüğü siyasi-iktisadiideolojik özel-sınırı yararların gözü kapalı olumlanmasına (Baruh, \& Popescu, 2017; Couldry, \& Mejias, 2019; Fuchs, 2017a; Hammond, 2017; Mann, \& Daly, 2019; Poel et al., 2018; Puschmann, \& Burgess, 2014; Shin, 2015; Qiu, 2015) yöneltilen tepkiler olarak da görülebilir. Nitekim, Hammond'un (2017, p. 414) işaret ettiği gibi büyük veri alanında 'algoritmik tahmin' hizmetleri veren şirketler ${ }^{2}$ geliştirdikleri algoritmalar yardımıyla ürettikleri milyonlarca içeriği, bunlar sanki şirket varlığıymışçasına çevrimiçi mecralarda 'bırakın veriniz hikayesini anlatsın' türünden sloganlarla ilan etmeye başlamışlardır. Başarı öyküleri üzerine kurulu bu sloganların maddi temelini ise büyük verinin hızla yükselen piyasa değeri oluşturmaktadır ki büyük veri piyasasının günümüzde 55 milyar doların üzerinde parasal bir büyüklüğe ulaştığı tahmin edilmektedir (Statista, 2020).

Bu çalışma, hem bir araştırma kaynağı-aracı hem de kendisi bir araştırma konusunesnesi haline dönüşmüş büyük veriyle ilgili iletişim alanından yükselen bilimsel, ticari, siyasal, kültürel, ideolojik vb. nitelikteki pek çok soruya yanıtların arandığı güncel bir literatür incelemesidir. Bu haliyle özellikle Türkçe literatürde önemli bir boşluğu doldurmaktadır. Türkçe literatür söz konusu olduğunda, büyük veri odaklı araştırma makaleleri kamu yönetimi, işletme, bilgi-belge yönetimi ve bilgisayar bilimleri gibi farklı disiplinler içinde yoğunlaşmış durumdadır. Büyük veri, bu makalelerde, ya kamu yönetimi ve işletmeler açısından ortaya çıkardığı olanaklar ve riskler bağlamında (Altunışık, 2015; Ayvaz, \& Salman, 2020), ya belge ve arşiv yönetimine olan etkileri temelinde (Cibaroğlu, \& Yalçınkaya, 2019) ya da doğrudan makine tabanlı analiz ve işleme eksenleri özelinde (Arslan, \& Kahraman, 2019) ele alınmaktadır. İletişim odaklı az sayıdaki çalışmada (Filibeli, 2019) ise, büyük veri, yapay zekâ ve makine öğrenimi algoritmaları üzerinden dijital tehditler (veri gizliliğinin ya da mahremiyetin ihlali) bağlamında ele alınmaktadır.

Çalışma, ayrıca, Türkiye'den konuya ilgi duyan araştırmacıların büyük veri etrafında dönen tartışmaları, ele alınan sorunları, kuramsal ve yöntemsel tercihleri derli-toplu görebilmeleri ve yerel bilgi birikimine katkı verilebilecekleri noktaları belirleyebilmeleri açısından ileride yapılacak çalışmalara ışık tutucu niteliktedir. Bu nedenle çalışma kapsamına dâhil edilen makaleler hem temsil edici bir örneklem oluşturmaları için 
sayıca yüksek (62 makale) tutulmuş, hem de bilimsel-akademik yönden nitelikli olmaları için tanınmış veritabanı kataloglarından (Web of Science'tan) seçilmiştir.

Çalışma girişin ardından araştırma tasarımı ve yöntemin anlatıldığı bir bölümle sürmektedir. Bu bölümde çalışmanın kapsamı yanında, makalelerin seçimi, okunması ve kodlanması hakkında bilgiler verilmektedir. Üçüncü bölümde ulaşılan bulgular sunulmaktadır. Bu bölümde bulgular büyük resmi görmemizi sağlayacak genel nitelikte olanlarla büyük veriye yaklaşım farklılıklarını görmemizi sağlayacak ayrışık nitelikte olanlar biçiminde kategorileştirilerek verilmiştir. Son bölümde ise sonuçlar tartışılmaktadır.

\section{AMAÇ VE YÖNTEM}

\section{Amaç}

Bu çalışma, iletişim alanı içinde kalarak, büyük veri etrafında dönen güncel tartışmaları, büyük veri analizi için tercih edilen kuramsal yaklaşımları ve kullanılan yeni yöntemleri açığa çıkarmayı amaçlamaktadır. Çalışma, bu amaca ulaşmak için Web of Science kapsamında yer alan iletişim eksenli nitelikli makaleleri odağına almaktadır.

\section{Yöntem}

Çalışma, büyük veriyi ya doğrudan kullanan ya da dolayımlayan literatürü incelemeyi hedeflediği için yalnızca dergi makalelerini kapsamına almıştır. Bir makale çalışmasının izin verdiği sınırlar içinde kalabilmek için konferans bildirileri, kitap bölümleri ve kitaplar zorunlu olarak kapsam dışı bırakılmıştır. Makalelerin seçimi için Web of Science kataloğunda yer alan dizinlerde ( $\mathrm{SSCl}, \mathrm{AHCl} v$ vb.) taranan dergilerden yararlanılmıştır. Bu tercih, diğer dizinlerde (Scopus, Islamicus, TR Dizin vb.) yer alan dergilerdeki çok sayıda makalenin dışarıda kalmasına neden olmakla birlikte çalışmanın nitelikli yayınları kapsamasını da sağlamıştır. Makalelerin seçiminde ilk olarak konusu büyük veri olan makaleler taranmış ve bulunmuştur. Çalışmanın amacı doğrultusunda, bu tarama yalnızca iletişim alanı içinde kalınarak gerçekleştirilmiştir. Böylece, alt konu başlıkları (siyasal iletişim, reklamcılık, kamusal alan vb.) farklılaşmakla birlikte tümü iletişim alanıyla ilgili 138 makaleye erişilmiştir. Bu makalelerden Ingilizce olmayanlar elenmiştir. Bunun nedeni, yazarların diğer dillerdeki eksikliğidir. Bu elemenin ardından araştırma örnekleminin geçerliliğini ve güvenilirliğini sağlamak üzere geriye kalan 120 makalenin özet ve giriş kısımları çalışmanın amaçları doğrultusunda her bir yazar tarafından gözden 
geçirilmiş ve üzerinde uzlaşılan toplam 70 makale çalışmanın amacına uygun bulunarak örnekleme dâhil edilmiştir. Ön okumayı takip eden ayrıntılı okumalar sırasında 8 makalenin daha konuyla doğrudan ilgisi zayıf görülmüş ve kapsam dışına çıkarılmıştır. Sonuç olarak çalışma eldeki 62 makaleden oluşan bir örneklem üzerinden gerçekleştirilmiştir.

Araştırma örneklemine dâhil edilen makaleler niteliksel içerik analiz tekniği kullanılarak okunmuştur. Niteliksel içerik analizi, sistematik kodlama işleminin kullanılarak eldeki verilerin tanımlanması ve yorumlanması için kullanılan bir araştırma yöntemdir (Assarroudi, Nabavi, Armat, Ebadi, \& Vaismoradi, 2018; Schreier, 2012). Söz konusu yöntem bu açıdan literatür değerlendirmeleri için oldukça elverişlidir. Elde edilen bulgular ise betimleyici bir yaklaşım benimsenerek ortaya konmuştur.

Ön okumalar sırasında makalelerin, iki ayrı hat takip edecek biçimde birbirlerinden ayrıştığı tespit edilmiştir. Buna bağlı olarak niteliksel içerik analiz tekniği kullanılarak yapılan ayrıntılı okumalarda bu ayrışmaya sadık kalınmıştır. Sözü edilen bu hatlarda makaleler, bir yanda doğrudan büyük veriye odaklanan, onu sorunsallaştıran, diğer yanda ise iletişim eksenli bir konuyu-sorunu büyük veri kümesiyle analiz eden çalışmalar olarak ayrışmaktadır. Bu nedenle hatlar arasındaki ayrışmanın bulgular düzeyine yansımasını sağlamak için Flick'in (2009) yaklaşımı benimsenmiş ve her iki hatta toplanan makaleler için iki ayrı analiz kategorisi oluşturulmuştur. Buna göre, ilk hattaki çalışmalar için oluşturulan kategori başlıkları (i) yazar ve tarih, (ii) araştırma konusu/alanı, (iii) kuramsal çerçeve, (iv) araştırma yöntemi, (v) yararlanılan örneklem-veri kümesi, (vi) verilerin toplandığı araç-platform ve (vii) ulaşılan bulgular olmuştur. İkinci hattaki çalışmalar için ise (i) yazar ve tarih, (ii) anahtar kavramlar, (iii) bilimsel nitelik (iv) akademik bağlam, (v) konuya yaklaşım tarzı ve (vi) ulaşılan sonuçlar şeklinde kategoriler belirlenmiştir.

Bu adımın ardından, Zhang ve Wildemuth'un (2009) önerdiği yaklaşıma bağlı kalınarak, oluşturulan kategorilerin çalışıp çalışmadığı her iki hattan seçilen beşer makalenin okunması yoluyla test edilmiş ve bundan olumlu sonuçlar alınmıştır. Makalelerin tümü Hsieh ve Shannon (2009) ile Elo ve Kyngas (2008) tarafından sunulan modellere sadık kalınarak okunmuştur. Buna göre, makale yazarlarından biri ilk hattaki makaleleri kuramsal yönleri ağır bastığı için önceden belirlenen kategoriler ışığında ayrıntılı olarak okumuş ve kodlamıştır. Aynı yazar, ikinci hattaki makaleleri ampirik yönleri ağır bastığı için önce hızlıca gözden geçirmiş, önemli görülen yerleri işaretlemiş, ardından yeni bir 
okumayla işaretlenen bu yerleri daha detaylı bir biçimde gözden geçirerek önceden oluşturulan kategorilere göre kodlamıştır. Makalenin ikinci yazarı, kodlamanın güvenilirlik ve geçerliliğini sağlamak için bir aylık bir periyodun ardından ilk yazarın izlediği aşamaları takip ederek kodlama sürecini yinelemiştir. Bu yineleme sonucunda, her iki kodlamanın da birbiriyle örtüşen sonuçlar ürettiği görülmüştür.

\section{BULGULAR}

İncelemeye konu olan makalelerin tümü üzerine yapılan analiz sonucunda üç ayrı genel bulguya ulaşılmıştır. Makalelerin iki ayrı hat oluşturduğuna dikkat çeken üçüncü genel bulgu bizi bulguları iki başlık altında toplamaya yöneltmiş̧ir. Bu kapsamda, incelemeye konu olan makalelerin tümü için geçerli olan sonuçlar genel bulgular olarak, iki ayrı hattın kendi içinde geçerli olan sonuçları ise bu hatlara özgü ayrışık bulgular olarak yorumlanmıştır.

\section{Genel Bulgular}

Tüm çalışmalar birlikte değerlendirildiğinde ulaşılan ilk genel bulgu, incelemeye konu olan çalışmaların yıllara göre dağılımına ilişkindir. Şekil 1'de görüleceği üzere, iletişim eksenli büyük veri çalışmaları 2012'den başlayarak yıllara göre farklılaşan yoğunluğa sahiptir. Bu kronolojik dağılıma daha yakından bakıldığında, büyük veri üzerine olan tartışmaların Boyd ve Crawford'un (2012) kültürel-teknolojik-akademik açılardan bütünlüklü ve eleştirel bir bakışla ele aldıkları referans niteliğindeki çalışmasıyla başladığı söylenebilir. Günümüze yaklaştıkça makaleler sayıca hem artmakta hem de konu başıkları farkıılaşarak çeşitlilik kazanmaktadır.

Örneğin on ikişer makalenin yayınlandığı 2014 ve 2018 yıllarına bakıldığında, daha genel konu-sorun başlıklarından daha özel konu-sorun başlıklarına doğru bir farklılaşma olduğu görülmektedir. 2014 yılındaki çalışmalarda reklam, pazarlama, kamuoyu araştırmaları ve izleyici ölçümleri gibi faaliyetlerin daha etkin-verimli pratikler haline getirilmesi için büyük verinin analizinde bilgisayarların, algoritmaların nasıl devreye sokulacağı, üçüncü parti yazılım kullanımının yarattığı sorunlar ya da etik konusunda var olan hukuki boşluğu gidermek için hangi kriterlerden hareket edilmesi gerektiği gibi az sayıda konu-sorun başlığı, genelleyici söylemler ('büyük veri güçtür') eşliğinde ve paradigmalara özgü bir kavrayışla (Puschmann, \& Burgess, 2014) ele alınmaktadır. 
Buna karşın 2018 yılındaki çalışmalarda hem konu-sorun başlıkları farklılaşmışçeşitlenmiş hem de bunlara ilişkin yaklaşımlar, kimi zaman kuramsal temellendirmelerle kimi zamanda çalışmanın bizzat içerdiği ya da betimlediği araştırmalardan, örnek olaylardan elde edilen bulgularla daha detaylandırılmış bir biçimde işlenmiştir. Örneğin 2014 yılında olduğu gibi 2018 yılında da etik sorunlar yine başat çalışma konularından biridir. Ancak bu kez aynı sorun-konu başlığı araştırma etiği, araştırmacının sorumluluğu, verisi toplanan kişinin rızası ve bu rızanın hukuki koşulları, mahremiyetin kapsamı, teşhircilik, veri ilişkilendirme ve yol açtığı zararın boyutları, meslek etiği, feminist etik, siyaset etiği, medya etiği, ağ etiği, etiğe ilişkin düzenleyici rejimler ya da ülkeler bazında karşılaştırmalı düzenleme rejimleri gibi onlarca alt başlık altında tartışmaya açılmaktadır.

Bu kronolojik dağılım açısından Boyd ve Crawford'un (2012) büyük veri üzerindeki gizemin kaldırılarak kapsamlı bir sorgulamadan geçirilmesi gerekliliğine işaret ettikleri çalışmanın bir başka etkisi de sosyal bilimlerle bilgisayar bilimleri alanlarında çalışan bilim insanlarını, araştırmacıları birbirleriyle daha fazla iş birliğine gitmeleri yönünde yaptıkları çağrının zamanla geniş bir çevrede kabul görmesidir. Araştırma örneklemine giren makaleler, yazarları ve çalışma alanları yönünden incelendiğinde büyük veriyi eleştirel bir bakışla ele alma gerekliliği yanında teknoloji ile sosyolojinin iş birliği çağrısının da dikkate alındığı görülmektedir. Nitekim örnekleme dâhil edilen 62 makaleden 42'si, farklı çalışma alanlarından gelen araştırmacıların katkı verdiği iki ve daha fazla yazarlı çalışma niteliğindedir.

İkinci genel bulgu, büyük veri olgusuyla ilişkilendirilen kavramlara ilişkindir. Bu bağlamda makalelerde yer verilen anahtar kavramlar Şekil 2'de görselleştirilmiştir. Bu anahtar kavramlar büyük veriyle ilgili çalışmalardaki yoğunlaşma alanlarının neler olduğunu anlamamıza yardım etmektedir. Bu kapsamda, büyük verinin en güçlü biçimde sosyal medya (verisi), veri analizi ve etik kavramlarıyla ilişkili olduğu söylenebilir. Bunları sırasıyla Twitter, niteliksel araştırma ve siyasal iletişim izlemektedir. Iletişim çalışmaları alanında araştırmacılar gerek mesleki gerekse toplumsal gerçekliğe ilişkin daha kapsamlı ve güncel veri ile çalışmak için giderek daha çok sosyal medya verisini, özellikle de siyasal iletişim söz konusu olduğunda Twitter platformundan edinilmiş olanları kullanmak istemekte, bunun için nitel ve nicel veri analizi tekniklerine başvurmakta ve bu durumun sıklıkla yaşanan bir sonucu olarak da ortaya çıkan çeşitli etik sorunlarla karşılaşmaktadırlar.

Üçüncü genel bulgu, makalelerin kendi aralarında sergilediği farklılaşmaya ilişkindir. Şekil 3'te görüleceği üzere, örnekleme dâhil olan çalışmalar temelde iki ana hat 
oluşturacak biçimde birbirlerinden ayrışmaktadır. Buna göre, ilk hatta yer alan 17 makale iletişim alanıyla ilgili, daha önce araştırma konusu olmuş bir konuyu (örneğin siyasal iletişim, kamusal alan, kamusal tartışmalar, gündem belirleme vb.) bu kez büyük bir veri kümesiyle analiz etmekte ve yeni bulgulara ulaşmaktadır. Ayrıca bu makalelerin hiçbirinin büyük verinin kendisini sorunsallaştırmadığı, aksine büyük veriyi araçsallaştırdığı, onu adeta verili kabul ettiği belirlenmiştir. Diğer taraftan, ikinci hatta yer alan 45 makalenin ise büyük verinin doğrudan kendisine odaklandığı, günümüzün belirsiz ve hızla değişen toplumsal ilişkiler ortamında, iletişim alanıyla doğrudan ya da dolaylı bir biçimde gerek yöntemsel, gerek kavramsal-kuramsal gerekse mesleki ve/veya toplumsal pratiklerin dönüşüm süreci içinde onu sorunsallaştırdığı,'yeşerttikleri umutlar've'neden oldukları kaygılar-korkular' bağlamında bulgulara ulaşarak bunlar üzerinden büyük veriye eleştirel yaklaştıkları görülmüştür. Yine Şekil 3'te yer verildiği üzere, büyük veriye doğrudan odaklanan çalışmalar kendi içlerinde yöntemsel, kavramsal-kuramsal ve mesleki-toplumsal pratiklerle ilişkili yaklaşımları açısından da ayrışmaktadırlar. Bu alt ayrışmada, mesleki-toplumsal pratiklerle ilişkili yaklaşımlar ise sorunlar ekseninde, yani başta etik ve kuramsal-yöntemsel olmak üzere ticari, siyasi ve kültürel-ideolojik sorunlar başlıklarında üçüncü bir ayrışma sergilemektedirler.

\section{Ayrışık Bulgular}

Bu başlık altında yer verilecek bulgular için yine Şekil 3'te oluşturulan ana ve tali hatlar kullanılmıştır. Buna göre, ilk ana hatta 17 makale bulunmaktadır. Bu makalelere ilişkin bulgular, Büyük Veri Dolayımlı Çalışmalar başlığı altında sıralanmıştır. İkinci ana hatta ise 45 makale bulunmaktadır ve bunlara ilişkin bulgular Büyük Veri Odaklı Çalışmalar başlığı altında sıralanmıştır.

\section{Büyük Veri Dolayımlı Çalışmalara İlişkin Ayrışık Bulgular}

Büyük veri dolayımlı 17 çalışmaya ilişkin bulgular toplu olarakTablo 1'de aktarılmaktadır. Buna göre ilk ayrışık bulgu makalelerin konu dağılımlarına ilişkindir. Ilginç bir biçimde medyanın gündem belirleme tezine odaklanan makaleler (Guo, \& Vargo, 2017; Neuman, Guggenheim, Jang, \& Bae, 2014; Vargo, \& Guo, 2017; Vargo, Guo, \& Amazeen, 2018) diğerlerine göre ağırlıklıdır. Bunları, izleyici araştırmaları ve ölçümleri (Feng, 2019; Kosterich, 2016; Nelson, \& Webster, 2016), siyasal iletişim ve siyasal kampanyalar (Guo, \& Vargo, 2015; Hokka, \& Nelimarkka, 2019; Konitzer, Rothschild, Hill, \& Wilbur, 2019), kamusal alan ve kamusal tartışmalar (Colleoni, Rozza, \& Arvidson, 2014; Kim, Brossard, 
Scheufele, \& Xenos, 2016) ve bilgisayar destekli iletişim (Carpenter, \& Amaravadi, 2019; Park, Baek, \& Cha, 2014) odaklı makaleler izlemektedir. Geri kalanlar temsil/söylem (Pentzold, Brantner, \& Fölsche, 2019), gazetecilik pratikleri (Tandoc Jr., \& Oh, 2017) ve dilbilim (Margolin, \& Markowitz, 2018) eksenli çalışmalardır.

İkinci ayrışık bulgu kullanılan kuramsal çerçeveye ilişkindir. Buna göre kuramsal çerçeve kullanan makalelerin sayısı kullanmayanlara göre ağırlıktadır. Gündem belirleme konusuna odaklanan çalışmalar yanında, siyasal iletişim ve siyasal kampanyalar ile kamusal alan ve kamusal tartışmalara eğilen makaleler (Guo, \& Vargo, 2015; Neuman et al., 2014; Vargo, \& Guo, 2017; Vargo, Guo \& Amazeen, 2018) çoğunlukla Gündem Belirleme Kuramı'na ve onun altında yer alan Ağ Gündem Belirleme Kuramı́na başvurmuşlardır. Bazı makalelerde (Feng, 2019; Guo, \& Vargo, 2017; Kosterich, 2016; Margolin \& Markowitz, 2018) tek bir kuram yerine birden fazla kuramsal yaklaşım benimsenmiştir. Öte yandan, bilgisayar destekli iletişim konusunu ele alan makaleler (Carpenter, \& Amaravadi, 2019; Park, Baek, \& Cha, 2014) Kültürel Farklılıklar Kuramı ve Toplumsal Normlar Kuramı́nı, kamusal alan ve kamusal tartışmaları inceleyen makaleler (Colleoni, Rozza, \& Arvidson, 2014) Kamusal Alan Kuramı'nı, siyasal iletişim konusunu analiz eden makaleler (Hokka, \& Nelimarkka, 2019) Duygulanımsal Ekonomi Kuramı́nı, izleyici araştırmaları ve ölçümlerine eğilen makaleler ise (Nelson, \&Webster, 2016) Çifte Risk Etkisi Kuramı́nı kullanmışlardır.

Bu hatta üçüncü ve en önemli ayrışık bulgu, kullanılan örneklem-veri seti, bu verinin toplandığı araç-mecra ve verinin analizi için kullanılan yönteme ilişkindir. Bu kapsamda, makalelerde kullanılan örneklemin-veri setinin toplanması için yalnızca iki makalede geleneksel medya mecralarının kullanıldığı, iki makalede geleneksel ve yeni medya mecralarının birlikte kullanıldığı, geri kalan 13 makalede ise yeni medya mecralarının tercih edildiği saptanmıştır. Bu kapsamda, gazete, radyo ve televizyon (Konitzer et al., 2019; Neuman et al., 2014; Pentzold, Brantner, \& Fölsche, 2019; Tandoc Jr., \& Oh, 2017) geleneksel mecralar olarak; haber web sayfaları (Guo, \& Vargo, 2017; Nelson, \& Webster, 2016; Vargo, \& Guo, 2017; Vargo, Guo, \& Amazeen, 2018), Twitter ve Facebook gibi sosyal medya uygulamaları (Colleoni, Rozza, \& Arvidson, 2014; Guo, \& Vargo, 2015; Hokka, \& Nelimarkka, 2019; Kim et al., 2016; Konitzer et al., 2019; Neuman et al., 2014; Park, Baek, \&Cha, 2014), forum sayfaları ya da bloglar (Neuman et al., 2014; Margolin, \& Markowitz, 2018), mobil uygulamalar (Carpenter, \& Amaravadi, 2019), sinema veri tabanları (Feng, 2019) ve en sonu reyting ölçüm sayfaları (Kosterich, 2016) yeni mecralar olarak kullanılmıştır. 
Ayrıca kullanılan mecranın doğası, toplanan örneklemin-veri setinin niteliğini belirlemiştir. Bu kapsamda, sosyal medya platformlarından, forum ya da bloglardan ve mobil uygulamalardan çekilen veriler kullanıcı içeriklerinden oluşurken, gazete, radyo ve televizyondan toplanan veriler kurumsal haber ya da görüntü içeriklerinden meydana gelmektedir. Burada göze çarpan unsur, verinin büyüklüğündeki farklılaşmadır. Bu bağlamda, kullanılan en büyük örneklem kümesi 1,7 milyar tweetten (Park, Baek, \& Cha, 2014), en küçük örneklem kümesi ise 450 gazete görselinden (Pentzold, Brantner, \& Fölsche, 2019) oluşmuştur. Bu ikisi arasında kalanlar, milyonlar, yüzbinler ve binlerle ifade edilen örneklem büyüklüğüyle yapılan çalışmalardır.

Çalışılan örneklemin büyüklüğü kullanılan yöntem üzerinde de az ya da çok belirleyici olmuştur. Buna göre, makalelerde veri setinin büyüklüğü araştırmacıları birden fazla yöntemi bir arada kullanmaya yöneltmiş görünmektedir. Örneğin, bazı makalelerde (Carpenter, \& Amaravadi, 2019; Konitzer et al., 2019; Kosterich, 2016; Nelson \& Webster, 2016; Neuman et al., 2014; Tandoc Jr. \& Oh, 2017; Vargo, Guo \& Amazeen, 2018) yalnızca tek bir nicel yöntem kullanılırken (örneğin içerik analizi, istatiksel analiz, regresyon analizi vb.), bazılarında (Feng, 2019; Park, Baek \& Cha, 2014; Vargo \& Guo, 2017) çoklu nicel yaklaşıma (örneğin sınıflandırma analizi, istatiksel analiz, içerik analizi vb.) başvurulmuştur. Daha da önemlisi, bazı makalelerde çoklu yöntem benimsenmiş olmasıdır. Bu kapsamda, kimi makalelerde (Hokka, \& Nelimarkka, 2019; Kim et al., 2016; Pentzold, Brantner, \& Fölsche, 2019) nicel (içerik analizi, sınıflandırma analizi vb.) ve nitel (söylem analizi, duygu analizi, yorumlama vb.) yöntemler birlikte kullanırken, kimilerinde (Guo, \& Vargo, 2015; Guo, \& Vargo, 2017) nicel ve sosyal ağ analiz tekniği bir arada kullanmıştır. Geri kalan makalelerde ise yine tek bir yöntem, örneğin sosyal ağ analizi (Colleoni, Rozza, \& Arvidson, 2014) ve bilgisayar destekli dilbilimsel analiz (Margolin, \& Markowitz, 2018) kullanılmıştır. Bu kapsamda sonuçlar bir bütün olarak değerlendirildiğinde nicel yöntemin makalelere hâkim olan yöntem olduğu söylenebilir. Öyle ki, 17 makaleden 15'i bu teknikten tam ya da kısmen yararlanmış görünmektedir.

Dördüncü ve son ayrışık bulgu makalelerin ulaştığı sonuçlara ilişkindir. İlk ana hatta yer alan makalelerin tümü özgün bir araştırma içerdiği için yazarların ulaştıkları sonuçlar da farklılaşmıştır. Bu nedenle tümünü kapsayıcı bir ya da birkaç genelleme yapmak yanıltıcı olabilecektir. Bunun yerine 17 makalenin her biri için Tablo 1'in son sütununda 'Temel Bulgular' başlığı altında yazarların ulaştıkları sonuçlar önemli bulguları da içerecek biçimde özlü olarak verilmiştir. 


\section{Büyük Veri Odaklı Çalışmalara İlişkin Ayrışık Bulgular}

Büyük veri odaklı 45 makale, büyük verinin kendisini sorunsallaştıran çalışmalardır. Bu makalelerle ilgili ilk ayrışık bulgu, çalışmaların genelde büyük veriyi tanımlama ya da çerçevelendirme çabası içinde olmalarıdır. Büyük veriyi anlamak-kavramak için gösterilen bu çaba öncelikle bu olgunun teknolojiyle adeta sarmalanmış dış kabuğunu kırmak ve iletişimcilerin içine sirayet edebileceği bir kapı aralamak şeklinde nitelendirilebilir. Bu çaba bağlamında Boyd ve Crawford'un (2012) çalışmalarında geliştirdikleri ve büyük veriyi salt teknolojik bir olgu³ olarak görmek yerine toplumsal yarar/sınırlı yarar karşıtlığı ekseninde eleştirel bir bakışla kültürel, teknolojik ve mitolojik boyutlarıyla birlikte kavranması gereken bir olgu olarak değerlendirdikleri hatta ya sadık kalındığı (Baruh \& Popescu, 2017; Chen \& Zhou, 2018; Lewis, Zamith, \& Hermida, 2013; Poel et al., 2018; Puschmann \& Burgess, 2014; Qiu, 2015; Zimmer, 2018) ya da araştırmacıların akademik ilgisinin üzerinde yoğunlaştı̆̆ı sorunun ayrıksı yanlarına göre kısmen eklemeler-katkılar yapıldığı (Athique, 2018; Fuchs, 2017a; Hammond, 2017; Leckner, \& Severson, 2019; Papacharissi, 2015; Shin, 2015) görülmüştür.

Bu ana eğilimlerin dışında kalan az sayıdaki kavramsallaştırma çabalarına daha çok geleneksel ile yeni teknoloji karşılaştırması üzerinden ilerleyen ve büyük veriyi, işlevselcifaydacı yanlarını öne çıkararak olumlayan (Ingrams, 2018; Sandoval-Martin, \& La-Rosa, 2018; Shin, 2015; Willson, \& Leaver, 2015) bir bakışın egemen olduğunu söyleyebiliriz. Bu bakışın ayrıt edici özelliği, büyük verinin toplumsal olanın bilgisini üretme ve daha iyi bir geleceğin inşasına katkı verme anlamında sunduğu olanakların büyüklük, hız ve çeşitlilik olarak salt nicel boyutlarla sınırlandırılmasıdır. Nitekim büyük verinin daha çok olumlu-faydacı yanlarının öne çıktığı çalışmalarda (Kelly, 2019; Veglis, \& Maniou, 2018), toplumsal olanın bilgisini üretmede devreye giren yeni araştırma ve veri analiz yöntemlerinin işlevselliği ve kapasitesi sıklıkla vurgulanmaktadır.

Çalışmaların bilimsel niteliği açısından bakıldığında ikinci ayrışık bulgu, büyük veriyle birlikte iletişim alanında görülen dönüşümün bir paradigma değişimi (Athique, 2018; Broussard, 2016; Couldry, \& Turow, 2014; Fuchs, 2017a; Fuchs, 2017b; Poel et al., 2018; Puschmann, \& Burgess, 2014; Shin, 2015; Thatcher, 2014; Veglis, \& Maniou, 2018) olarak yorumlanmasıdır. Bu nitelendirmede savlandığı üzere geleneksele oranla büyük veri, son dönemde bilimsel açıdan daha kapsamlı ve geçerli çalışmaların yapılmasını, dolayısıyla da toplumsal dönüşümün daha yakından izlenebilmesini mümkün kılmaktadır. Başka bir ifadeyle, bir tarafta araştırmacının gereksinimini karşılayacak ölçekte bir 
örneklemden anket gibi tekniklerle veri toplayan, çeşitli istatistiki yazılımlar yardımlıyla bunların tetkik-analiz edilmesine dayalı emek yoğun geleneksel yöntemler; diğer tarafta ise örneklemin temsil ettiği ölçeğin de ötesine geçen, artık büyük veriyle temsil edilen, farklı kaynaklardan-farklı formatlarda verilerle adeta 'kendiliğinden dolan' bir veri havuzundan çeşitli algoritmalarla veri çekilmesine-toplanmasına-ayıklanmasına-analiz için veri setleri şeklinde organize edilmesine-depolanmasına dayalı teknoloji yoğun yeni bilimsel araştırma yöntemleri yer almaktadır.

Çalışmanın makale seçkisi iletişimsel yaklaşımları öncelemekle birlikte bu yaklaşımlar disiplinlerarası bir çalışma alanı oluşturduğu için büyük verinin kendisinin sorunsallaştıııması noktasında ikinci ana hatta dikkatler büyük verinin alana yaptığı ya da yapabileceği katkının akademik niteliği üzerinde toplanmaktadır. Bu bağlamda üçüncü bulgu, makalelerin büyük veriden araştırmalar yoluyla elde edilecek çıktıların niteliğini bireyselden toplumsala geniş bir yelpaze içerisinde yarar ve zarar karşıtığı ekseninde tartışıyor olmalarıdır. Söz konusu tartışma çerçevesinde kimi yazarların (Arsenault, 2017; Fairfield, \& Shtein 2014; Kelly, 2019; Kshetri, 2014; Zimmer, 2018) birey/ grup/kamu/toplum ayrımı yapmadan, yararı en çoklaştırmak için zararı en aza indirgeme kaygısıyla hareket ettikleri, kimi yazarların ise (Athique, 2018; Couldry \& Turow, 2014; Halavais, 2015; Light, Mitchell, \& Wikström, 2018; Willson, \& Leaver, 2015) bu kategoriler arasında belli önceliklerin belirlenmesi gerektiğine vurgu yaparak bunların evrensel nitelikte ilkelere dönüştürülmesinde ısrarcı oldukları görülmüştür. Yazarların bu ısrarlarının gerisinde iki önceliğin yattığı belirlenmiştir: Illki, yeni yeni deneyimlenen büyük veri olgusuna ilişkin olarak örneğin reklam-pazarlama-halkla ilişkiler (Arsenault, 2017; Chen, \& Zhou, 2018; Couldry, \& Turow, 2014) ya da gazetecilik (Broussard, 2016; Guo, Vargo, Pan, Ding, \& Ishwar, 2016; Hammond, 2017; Lewis et al., 2013; Parasie, 2015; SandovalMartin \& La-Rosa, 2018; Yang, 2016) gibi mesleki pratikler ekseninde etik ilkelerin belirlenmesinde araştırmayı uygulayanlar yanında araştırmaya konu olan bireylerin de söz hakkı olması (bilgilendirmeye dayalı rıza gibi) gerektiğidir (Baruh, \& Popescu, 2017; Couldry, \& Turow, 2014; Fairfield, \& Shtein 2014; Light, Mitchell, \& Wikström, 2018; Zimmer, 2018). Íkincisi ise bilimsel araştırmalar söz konusu olduğunda toplumsal ölçekte veriyi toplayan, işleyen ve depolayan aktörlerin (büyük veriden yararlanan başta araştırmacı olmak üzere sosyal medya platformları, devlet, iş dünyası, sivil toplum kuruluşları gibi kurum ve kuruluşlar) faaliyetlerini organize ederlerken bu ilkelere ne ölçüde sadık kaldıklarının kurumsal denetiminin sağlanmasıdır (Boyd, \& Crawford, 2012; Chen, \& Zhou, 2018; Driscoll, \& Walker, 2014; Fuchs, 2017a; Kshetri, 2014; Qiu, 2015; Poel et al., 2018; Yeh, 2018; Zimmer, 2018). 
İkinci hatta yer alan makalelere ilişkin dördüncü ayrışık bulgu, bu makalelerin kendi aralarındaki türsel farklılaşmaya ilişkindir. Buna göre, vaka çalışmalarına yaslanan kuramsal-kavramsal nitelikteki makaleler (Boyd, \& Crawford, 2012; Crawford, Miltner, \& Gray, 2014; Driscoll, \&Walker, 2014; Halavais, 2015; Lewis et al., 2013; Luka, \& Millette, 2018; Qiu, 2015; Papacharissi, 2015), araştırma makalelerine (Chen, \& Zhou, 2018; Guo et al., 2016; Light, Mitchell, \& Wikström, 2018; Yang, 2016) göre ağırlıktadır. Dahası, bu hat içinde, çalışmasını özgün bir araştırma ile destekleyen ve araştırma yönteminin seçiminde algoritma destekli nicel yöntem ve analiz tekniklerini tercih eden yazarlara oranla (Lewis, Zamith, \& Hermida, 2013; Lewis, \& Westlund, 2014; Poel et al., 2018), verinin belli yanlılıklar-eksiklikler-belirsizlikler taşıyor olmasını gerekçe göstererek nitel yöntem ve analiz tekniklerini tercih eden yazarlar (Boyd, \& Crawford, 2012; Chen, \& Zhou 2018; Hammond, 2017; Sandoval-Martin, \& La-Rosa, 2018; Stockmann, 2018; Willson, \& Leaver, 2015) daha ağırlıklıdır. Bu iki yaklaşımın yanı sıra alanın bilgi birikimini destekleyecek araştırma türü olarak nitel araştırma ve nicel analiz tekniklerinin önemine vurgu yapan ve her ikisini harmanlamanın gerekliliğine işaret eden çalışmalar ise (Leckner, \& Severson 2019; Luka, \& Millette, 2018; Yang, 2016) azınlıkta kalmaktadır.

Bu hatta beşinci ayrışık bulgu, hemen hemen tüm makalelerin büyük veriye beş ana sorun başlığı altında odaklanmalarıdır. Aslında bunlar büyük veri öncesinde de gerek akademi içinde gerekse dışında geçerli olan sorunlardır. Ancak büyük veri ile birlikte nitelikleri değişmiş, kapsamları genişlemiştir. Dolayısıyla bu eski sorunlara'yeni' bir bakışla yaklaşma gereği ortaya çıkmıştır. Bunlardan ilki, özellikle sosyal medyadan çekilen verilerin analizi, analiz sonuçlarının açıklanması, depolanması ya da kullanımı söz konusu olduğunda karşılaşılan etik sorunlardır. Daha önce genel bulguların ilkinde değinildiği üzere etik sorunlar, hemen hemen tüm makalelerde yazarların bir biçimde dile getirdiği ortak sorun başlığıdır. İkinci önemli başlık, kuramsal-yöntemsel zorluklarla ilgilidir. Yazarların bu soruna yaklaşımları belli noktalarda farklılaşmaktadır. Örneğin kimi yazarlar (Boyd, \& Crawford, 2012; Panger, 2016) örneklem kümesinin kurgusal olmasını, kimileri (Light, Mitchell, \&Wikström, 2018; Mahrt, \& Scharkow, 2013) araştırma tasarımının sadece örneklem kümesinin nicel büyüklüğünü esas almasını, kimileri de (Chan, 2015; Puschmann, \& Burgess, 2014; Thatcher, 2014) araştırmacının büyük veriden ne ölçüde yararlanabildiğini tartışmaya açmaktadır. Bu sorunu sırasıyla ticari, siyasal ve kültürel-ideolojik sorunlar izlemektedir. Bu üç soruna yönelik yaklaşım farklılıklarına örnekler vermek gerekirse, bazı yazarlar (Chen, \& Zhou 2018) ticari sorundan büyük verinin ticari yarar için kullanışlı hale getirilmesinde yaşanan güçlükleri (örneğin lisans ücretleri), bazı yazarlar ise (Baruh, \& Popescu, 2017; Halavais, 2015; Yeh, 2018) toplumsal 
yararın veri piyasasının kurallarına tabi olmasının yarattığı sorunları anlamaktadır. Siyasi soruna büyük verinin sahipliği anlamında hem uluslararası (Couldry, \& Mejias, 2019; Mann, \& Daly, 2019) hem de ulusal ölçekte (Andrejevic, 2014; Baruh, \& Popescu, 2017; Chan, 2015; Ingrams, 2018; Poel et al., 2018; Stockmann, 2018; Thatcher, 2014) siyasetçi/seçmen ilişkilerinde yaşanan yeni eşitsizlikler-yeni bağımlılık ilişkileri bağlamında 'veri uçurumu' nitelendirmesiyle yaklaşan yazarlar ağırlıktadır. Büyük veriye doğrudan odaklı bakışın kültürel-ideolojik sorunlara yaklaşımında ise, büyük verinin sıradan insanlar için bir muamma olarak kalmasının yarattığı teknolojik fetişizm (Crawford, Miltner, \& Gray, 2014; Puschmann, \& Burgess, 2014), sınırsız-derin gözetim (Fuchs, 2017b; Hogan, \& Shepherd, 2015; Lewis et al., 2013; Mann, \& Daly, 2019) ve toplumsal parçalanmışlık (Driscoll, \& Walker, 2014; Mahrt, \& Scharkow, 2013; Shin, 2015) gibi vurgular öne çıkmaktadır.

Bu ikinci ana hattaki makaleler için sözünü edeceğimiz altıncı ve son ayrışık bulgu büyük verinin ne anlama geldiğiyle ilişkilidir. Bu kapsamda, makalelerde büyük verinin 'kuramın sonu' ya da 'sayıların', sosyal medyada kullanıcı pratiklerinin ya da empirik verinin 'gerçekliğin eksiksiz-saf temsili' anlamına gelmediği konusunda (Andrejevic, 2014; Boyd, \& Crawford, 2012; Couldry, \& Mejias, 2019; Crawford, Miltner, \& Gray, 2014; Halavais, 2015; Qiu, 2015; Thatcher, 2014) büyük bir uzlaşı olduğu görülmüştür.

\section{TARTIŞMA VE SONUÇ}

Bu çalışma kapsamına giren literatür dikkate alındığında elde edilen genel ve ayrışık bulgulardan bazı sonuçlar çıkarmak olasıdır. Öncelikle, büyük veri dolayımlı çalışmalara (17 makale) oranla doğrudan büyük veriye odaklanan çalışmaların (45 makale) daha ağırlıklı olduğu yönündeki bulguyu, iletişimsel eksenli büyük veri çalışmalarının ele aldıkları sorunu büyük veri üzerinden anlatmaya girişmek yerine onu anlama ve anlamlandırma çabası içinde olduklarının bir göstergesi olarak yorumlamak mümkündür. Buna bağlı olarak toplumun bilgisini-kuramını, toplumsal ilişkilerin taraflarını karşılıklı etkileşimleri bağlamında, sözlerinden ve eylemlerinden hareketle üretmeye çalışan iletişimciler için büyük verinin metaforik (Puschmann, \& Burgess, 2014), soyut-mecazi bir gerçeklik olma durumundan henüz bütünüyle sıyrıldığını da söylemek zor görünmektedir.

Ancak gerek genel gerekse ayrışık bulgular dikkate alındığında bu literatür incelemesi, karşılıklı etkileşime aracılık eden mesajlardan-enformasyondan yola çıkan iletişimsel 
eksenli büyük veri çalışmalarının, toplumsal olana dair bilgiyi üretme çabasında büyük veriyi araçsalcı bir yaklaşımdan ziyade ilişkisel bir yaklaşımla ele alma-yararlanma eğiliminde olduğunu da ortaya koymuştur. Çok sayıda makalede doğrudan ya da dolaylı olarak sorulan sorular - 'bu veri nereden geliyor?' (Hammond, 2017), 'nicel veri analizi toplumu bütünlüklü olarak anlamamıza gerçekten yardımcı olabilecek mi? (Kelly, 2019; Leckner, \& Severson, 2019), 'araştırmacılar olarak bize sunulan veriler aslında verisi toplanabilecek türden kurgusal ilişkiler mi?' (Couldry, \& Mejias, 2019), 'insan davranışları elektronik izler üzerinden modellenebilir mi?' (Fuchs, 2017b), 'veri eksik-yanlı-sınırlı ya da değişken olabilirken onu en gelişmiş bilgisayarlarla-algoritmalarla analiz ediyor olmamız topluma dair doğru-kesin bulgulara ulaşabileceğimiz anlamına gelir mi? (Crawford et al., 2014; Baruh, \& Popescu, 2017), 'büyük veriden beklentiler büyüktü ama sonuçlar oldukça sınırlı kalmadı mı?' (Chan, 2015; Poel et al., 2018), 'araştırma etiğini hiçe saydığımızda toplum adına ürettiğimiz bilgiyi de değersizleştirmiyor muyuz?' (Halavais, 2015), 'siyasi, ticari, kültürel, bilimsel her türden başarının kahramanı büyük veri ise artık ona tapınmamız mı gerekecek?' (Thatcher, 2014) - bizi ister istemez iletişim araştırmacılarının büyük veri analizini sayılara bakarak değil, insanlar arasındaki ilişkileri dikkate alarak yaptıklarına dair bir düşünceye sevk etmektedir.

Ayrıca bu çalışama iletişim araştırmacılarının büyük veriden akademik amaçlı yararlanma konusunda iki temel zorlukla karşı karşıya kaldıklarını ortaya koymuştur. Illki araştırmacının veri toplama, ayıklama ve analiz etmede bilgisayar-algoritma destekli araştırma yöntem ve tekniklerini etkin kullanma becerilerinin yetersizliği, ikincisi ise araştırmacının hazır-satın alınmış ya da erişimi sınırlandırılmış veri kümesiyle çalışmaya başladığında karşı karşıya kaldığı etik sorunların araştırmanın sonuçlarını tartışılır hale getirmesidir. Bu durumda Boyd ve Crawford'un (2012, p. 664) sosyal bilimlerle mühendislik bilimleri arasında iş birliği çağrısı farklı bir anlam kazanmaktadır. Toplumsal yaşamın her alanında yaşanan hızı değişim ve beraberinde aratan belirsizlik ortamında büyük veri, tekniğin-teknolojinin sınırlı yararın üretimine katkı vermesi anlamında yeterince etkin kullanılmaktadır. Nitekim gerek bireysel gerekse işletmelerkurum ve kuruluşlar düzeyindeki başarı öykülerinde büyük veri, insanın hızlı ve doğru karar verebilme becerisinde asıl pay sahibi olarak gösterilmektedir. Dahası büyük veri yoluyla bu durumun hız kesmeden gelecekte de devam edeceği söylenmektedir. Ancak ası önemli olan, Boyd ve Crawford'un (2012) bu çağrısını toplumsal yararın göz ardı edilebilir olduğu düşüncesine karşı eleştirel bir tutum takınarak mühendislik bilimlerini toplumsal yararı ortak üretme adına akademik iş birliğine açık bir davet olarak yorumlamaktır. 
Oysa, büyük veri ticari bir meta olmakla birlikte, bilimsel yarar adına kullanılabilecek bir araç ve aynı zamanda soyut toplumsal ilişkilerin somutlaştırılabilmesine olanak sağlayan bir araştırma nesnesi olduğu için akademik ilgiyi sonuna kadar hak etmektedir. Ancak ayrımında olunması gereken husus, iletişim araştırmacılarının ister istemez kendi yararlarını mı yoksa toplumun yararını mı düşünecekleri noktasında bir ikilemle karşı karşıya kaldığı ve birini seçmeleri gerektiği gibi bir durumun aslında sahte bir zorunluluk olarak dışarıdan dayatılmakta olduğudur. İletişim araştırmacıları, akademik yararlarınıintiyaçlarını gözetirken yanı sıra toplumun intiyaçlarını-yararını da karşılayabilecek pozisyonunu henüz kaybetmemiştir. Bu literatür incelemesinin de ortaya koyduğu üzere, bilgisayar ya da algoritma destekli de olsa büyük verinin yorumlanması kuramsal bilginin yorumlanmasından çok daha zordur ve genel olarak sosyal bilimler özel olarak da iletişim alanındaki araştırmacılara çok daha fazla ihtiyaç var gibi görünmektedir. Esasen böylesi bir sahte tercihi bir zorunluluk olarak akademik dünyaya dayatan, özelsınırlı yararlarını en çoklaştırmak için onları kendi yanına çekmeye çalışan, büyük veriye erişimi sözde toplumsal yarar adına sınırlandıran ya da şirket varlığıymışçasına kullanımına ambargo koyan kesimlerdir. Bunun üstesinden gelebilmenin yolunu Boyd ve Crawford (2012, pp. 664, 665) çok önceden göstermişlerdir. Yazarların da belirttikleri gibi, araştırmacılar, bilim insanları yeni akademik el birliklerinin, disiplinlerarası yeni dayanışma biçimlerinin arayışı içinde olmayı sürdürmek ve bulmak durumundadırlar.

Sonuç olarak bu çalışma, büyük veriye ilişkin Türkçe literatürde var olan boşluğu doldurmanın yanı sıra mevcut literatürde ele alınan konu ve sorunları topluca ortaya koyarak ileride bu konuya ilişkin olarak iletişim alanında yapılacak çalışmalar için de yol gösterici olmayı hedeflemiştir. Nitekim Türkçe literatür söz konusu olduğunda büyük veriye ilişkin çalışmalar sosyal bilimler alanı dışında yoğunlaşmaktadır. Sosyal bilimler alanı içinde kalan az sayıdaki çalışma ise kamu yönetimi, işletme ve bilgi-belge yönetimi gibi iletişimden ayrı disiplinler içinde yer almaktadır. Bu bağlamda, çalışmanın ortaya koyduğu konu başlıkları ve sorun alanları, büyük veriyi iletişimsel perspektiften ele alacak araştırmaların gerek kuramsal gerek yöntemsel açıdan yeni bir kavrayışla yapılandırımasına katkı sunacaktır. Bu çalışmada ortaya konulduğu üzere, iletişim araştırmacılarının özellikle büyük veriyi geleneksel yöntemlerden farklı araştırma tekniklerini kullanarak analiz etmeleri iletişim literatürünün bu kulvarda da genişlemesine ve zenginleşmesine olanak tanıyacaktır. 


\section{SON NOTLAR}

1. Shin, $(2016$, p. 849) devletlerin büyük veriye duydukları ilgiye örnek olarak Kore hükümetince aralarında üniversitelerin, İnternet-telekomünikasyon servis sağlayıcılarının ve bilişim sektörü ana üreticilerinin yer aldığı aktörlerle iş birliği içinde oluşturulan Elektronik Telekom Araştırma Enstitüsü'nü vermektedir. Bu enstitünün farklı kaynaklardan günlük veri toplama kapasitesi 90 milyar veri parçası gibi devasa boyuttadır. Shin (2016, p. 849) makalesinde Kore hükümetinin 2014 yılında enformasyon altyapısı ile büyük veri projeleri için planladığı yatırım bütçesinin 58,4 milyon Amerikan Doları olduğuna da dikkat çekmektedir.

2. Hammond (2017, p. 414), Narrative Science adlı şirketin daha 2012 yılında, gelecek 15 yıl içinde haber içeriklerinin yüzde doksanının algoritmalar tarafından yazılabileceği tahmininde bulunduğunu, raporlarında 2013 yılında tek başına 300 milyon içerik ürettiğini açıkladığını belirtmektedir.

3. Arsenault (2017, p. 9) büyük verinin ağırlıklı olarak teknolojik bir olgu olarak görülüpdeğerlendirilmesinde Google ve Yahoo gibi dijital platformların finansman yardımıyla 2007 yılında bir dizi bilgisayar üzerinden veri işleme ve paylaşımında bulunmaya olanak veren Hadoop isimli açık kaynak yazılımının devreye girişinin önemli bir yeri olduğunu ileri sürmektedir. Yazara göre (2017, p. 9) teknik-teknolojik kavrayış açısından verinin 'büyük' olarak nitelendirilmesi aslında nicel bir büyüklüğe tekabül etmektedir. Bu nicel büyüklük de tek bir bilgisayar tarafından işlenemeyecek büyüklükte-genişlikte bir veri dizisine tekabül etmektedir.

Hakem Değerlendirmesi: Dış bağımsız.

Çıkar Çatışması: Yazarlar çıkar çatışması bildirmemiştir.

Finansal Destek: Yazarlar bu çalışma için finansal destek almadığını beyan etmiştir.

Peer-review: Externally peer-reviewed.

Conflict of Interest: The authors has no conflict of interest to declare.

Grant Support: The authors declared that this study has received no financial support.

\section{KAYNAKLAR}

Altunışık, R. (2015). Büyük veri: Fırsatlar kaynağı mı yoksa yeni sorunlar yumağı mı? Yıldız Social Science Review, 1(1), 45-76. https://dergipark.org.tr/tr/pub/yssr/issue/21899/235390 Andrejevic, M. (2014). The big data divide. International Journal of Communication, 8, 1673-1689. 
Arsenault, A., H. (2017). The datafication of media: Big data and the media industries. International Journal of Media \& Cultural Politics, 13(1-2), 7-24. https://doi.org/10.1386/macp.13.1-2.7_1

Arslan, F., \& Kahraman, H. (2019). Yapay zekâ tabanlı büyük veri yönetim aracı. Journal of Investigations on Engineering and Technology, 2(1), 8-21. https://dergipark.org.tr/tr/pub/jiet/issue/48409/602203

Assarroudi, A., Nabavi, F. H., Armat, M. R., Ebadi, A., \& Vaismoradi, M. (2018). Directed qualitative content analysis: The description and elaboration of its underpinning methods and data analysis process. Journal of Research in Nursing, 23(1), 42-55. https://doi.org/10.1177/1744987117741667

Athique, A. (2018). The dynamics and potential of big data for audience research. Media, Culture \& Society, 40(1), 59-74. https://doi.org/10.1177/0163443717693681

Ayvaz, S., \& Salman, Y. (2020). Türkiye'de firmaların büyük veri teknolojileri bilinirliği ve kullanımı analizi. Avrupa Bilim ve Teknoloji Dergisi, 14(18), 728-737. https://doi.org/10.31590/ejosat.675247

Baruh, L., \& Popescu, M. (2017). Big data analytics and the limits of privacy self-managements. New Media \& Society, 19(4), 579-596. https://doi.org/10.1177/1461444815614001

boyd, d., \& Crawford, K. (2012). Critical questions for big data. Information, Communication \& Society, 15(5), 662679. https://doi.org/10.1080/1369118X.2012.678878

Broussard, M. (2016). Big data in practice, enabling computational journalism through code-sharing and reproducible research. Digital Journalism, 4(2), 266-279. https://doi.org/10.1080/21670811.2015.1074863

Carpenter, C. J., \& Amaravadi, C. S. (2019). A big data approach to assessing the impact of social norms: Reporting one's exercise to a social media audience. Communication Research, 46(2), 236-249. https://doi. org/10.1177/0093650216657776

Chan, A. (2015). Big data interfaces and the problem of inclusion. Media, Culture and Society, 37(7), 1078-1083. https://doi.org/10.1177/0163443715594106

Chen, H., \& Zhou L. (2018). The myth of big data: Chinese advertising practitioners' perspective. International Journal of Advertising, 37(4), 633-649. https://doi.org/10.1080/02650487.2017.1340865

Cibaroğlu, M., \& Yalçınkaya, B. (2019). Belge ve arşiv yönetimi süreçlerinde büyük veri analitiği ve yapay zekâ uygulamaları. Bilgi Yönetimi, 2(1), 44-58. https://doi.org/10.33721/by.570634

Colleoni, E., Rozza, A., \& Arvidsson, A. (2014). Echo chamber or public sphere? Predicting political orientation and measuring political homophily in twitter using big data. Journal of Communication, 64(2), 317-332. https://doi.org/10.1111/jcom.12084

Couldry, N., \& Mejias, U. A. (2019). Data colonialism: Rethinking big data's relation to the contemporary subject. Television \& New Media, 20(4), 336-349. https://doi.org./10.1177/1527476418796632

Couldry, N., \& Turow, J. (2014). Advertising, big data, and the clearance of the public realm: Marketers' new approaches to the content subsidy. International Journal of Communication, 8, 1710-1726.

Crawford, K., Miltner, K., \& Gray, M. L. (2014). Critiquing big data: Politics, ethics, epistemology. International Journal of Communication, 8, 1663-1672. 
Driscoll, K., \& Walker, S. (2014). Working within a black box: Transparency in the collection and production of big Twitter data. International Journal of Communication, 8, 1745-1764.

Elo, S., \& Kyngäs, H. (2008) The qualitative content analysis process. Journal of Advanced Nursing, 62(1), $107-115$. https://doi.org/10.1111/j.1365-2648.2007.04569.x

Fairfield, J., \& Shtein H. (2014). Big data, big problems: Emerging issues in the ethics of data science and journalism. Journal of Mass Media Ethics, 29, 38-51. https://doi.org/10.1080/08900523.2014.863126

Feng, G. C. (2019). A comparative study of the online film ratings of US and Chinese audiences: An analytical approach based on big data. International Communication Gazette, 81(3), 283-302. https://doi. org/10.1177/1748048518767799

Filibeli, T. (2019). Big data, artificial intelligence, and machine learning algorithms: A descriptive analysis of the digital threats in the post-truth era. Galatasaray Üniversitesi Iletişim Dergisi, 31, 91-110. https://doi. org/10.16878/gsuilet.626260

Fuchs, C. (2017a). From digital positivism and administrative big data analytics towards critical digital and social media research! European Journal of Communication, 32(1), 37-49. https://doi.org/10.1177/0267323116682804

Fuchs, C. (2017b). Günter Anders' undiscovered critical theory of technology in the age of big data capitalism. Triple C, 15(2), 582-611.

Guo, L., \& Vargo, C, J. (2017). Global intermedia agenda setting: A big data analysis of international news flow. Journal of Communication, 67(4), 499-520. https://doi.org/10.1111/jcom.12311

Guo, L., \& Vargo, C. (2015). The power of message networks: A big-data analysis of the network agenda setting model and issue ownership. Mass Communication and Society, 18(5), 557-576. https://doi.org/10.1080/1520 5436.2015.1045300

Guo, L., Vargo, C. J., Pan, Z., Ding, W., \& Ishwar, P. (2016). Big social data analytics in journalism and mass communication: Comparing dictionary-based text analysis and unsupervised topic modeling. Journalism \& Mass Communication Quarterly, 93(2), 332-359. https://doi.org/10.1177/1077699016639231

Halavais, A. (2015). Bigger sociological imaginations: framing big social data theory and methods. Information, Communication \& Society, 18(5), 583-594. https://doi.org/10.1080/1369118X.2015.1008543

Hammond, P. (2017). From computer-assisted to data-driven: Journalism and big data. Journalism, 18(4), 408424. https://doi.org/10.1177/1464884915620205.

Hogan, M., \& Shepherd, T. (2015). Information ownership and materiality in an age of big data surveillance. Journal of Information Policy, 5, 6-31. https://www.jstor.org/stable/10.5325/jinfopoli.5.2015.0006

Hokka, J., \& Nelimarkka, M. (2019). Affective economy of national-populist images: Investigating national and transnational online networks through visual big data. New Media \& Society, 1-23. https://doi. org/10.1177/1461444819868686

Hsieh, H. F., \& Shannon, S. E. (2005). Three approaches to qualitative content analysis. Qualitative Health Research, 15(9), 1277-1288. https://doi.org/10.1177/1049732305276687 
Ingrams, A. (2018). Public values in the age of big data: A public information perspective. Policy and Internet, 11(2), 128-148. https://doi.org/10.1002/poi3.193

Japec, F., Kreuter, F., Berg, M., Biemer, P., Decker, P., Lampe, C. ... , Lane, J., O'nell, C., \& Usher, A. (2015). Big data in survey research. Public Opinion Quarterly, 79(4), 839-880. https://doi.org/10.1093/poq/nfv039

Kelly, J. P. (2019). Television by the numbers: The challenges of audience measurement in the age of big data. Convergency: The International Journal of Research into New Media Technologies, 25(1), 113-132. https://doi. org/10.1177/1354856517700854

Kim, J., Brossard, D., Scheufele, D. A., \& Xenos, M. (2016). 'Shared' information in the age of big data: Exploring sentiment expression related to nuclear energy on Twitter. Journalism \& Mass Communication Quarterly, 93(2), 430-445. https://doi.org/10.1177/1077699016640715

Konitzer, T., Rothschild, D., Hill, S., \& Wilbur, K. C. (2019). Using big data and algorithms to determine the effect of geographically targeted advertising on vote intention: Evidence from the 2012 U.S. presidential election. Political Communication, 36(1), 1-16. https://doi.org/10.1080/10584609.2018.1467985

Kosterich, A. (2016). Reconfiguring the 'hits': The new portrait of television program success in an era of big data. International Journal on Media Management, 18(1), 43-58. https://doi.org/10.1080/14241277.2016.1166431

Kshetri, N. (2014). Big Data's impact on privacy security, and consumer welfare. Telecommunications Policy, 38, 1134-1145. http://dx.doi.org/10.1016/j.telpol.2014.10.002

Leckner, S., \& Severson P. (2019). Exploring the meaning problem of big and small data through digital method triangulation. Nordicom Review, 40(1), 79-94. https://doi.org/10.2478/nor-2019-0015

Lewis, S. C., \& Westlund, O. (2014). Big data and journalism: Epistemology, expertise, economics, and ethics. Digital Journalism, 3(3), 447-466. https://doi.org/10.1080/21670811.2014.976418

Lewis, S. C., Zamith, R., \& Hermida, A. (2013). Content analysis in era of big data: A hybrid approach to computational and manual methods. Journal of Broadcasting \& Electronic Media, 57(1), 34-52. https://doi.or $\mathrm{g} / 10.1080 / 08838151.2012 .761702$

Light, B., Mitchell, P., \& Wikström, P. (2018). Big data, method and the ethics of location: A case study of a hookup app for men who have sex with men. Social Media + Society, 4(2), 1-10. https://doi.org/10.1177/2056305118768299

Luka, M. E., \& Millette, M. (2018). (Re)framing big data: Activating situated knowledges and a feminist ethics of care in social media research. Social Media + Society, 4(2), 1-10. https://doi.org/10.1177/2056305118768297

Mahrt, M., \& Scharkow, M. (2013). The value of big data in digital media research. Journal of Broadcasting \& Electronic Media. 57(1), 20-33. https://doi.org/10.1080/08838151.2012.761700

Mann, M., \& Daly, A. (2019). (Big) data and the north-in-south: Australia's informational imperialism and digital colonialism. Television \& New Media, 20(4), 379-395. https://doi.org/10.1177/1527476418806091

Margolin, D., \& Markowitz, D. M. (2018). A multitheoretical approach to big text data: Comparing expressive and rhetorical logics in yelp reviews. Communication Research, 45(5), 688-718.

https://doi.org/10.1177/0093650217719177 
Nelson, J. L., \& Webster, J. G. (2016). Audience currencies in the age of big data. International Journal on Media Management, 18(1), 9-24. https://doi.org/10.1080/14241277.2016.1166430

Neuman, W.R., Guggenheim, L., Jang, S. M., \& Bae, S. Y. (2014). The dynamics of public attention: Agenda-setting theory meets big data. Journal of Communication, 64(2), 193-214. https://doi.org/10.1111/jcom.12088

Panger, G. (2016). Reassessing the Facebook experiment: Critical thinking about the validity of big data research. Information, Communication \& Society, 19(8), 1108-1126. https:/doi.org/10.1080/1369118X.2015.1093525

Papacharissi, Z. (2015). The unbearable lightness of information and the impossible gravitas of knowledge: Big Data and the makings of a digital orality. Media, Culture \& Society, 37(7), 1095-1100. https://doi. org/10.1177/0163443715594103

Parasie, S. (2015). Data-driven revelation? Epistemological tensions in investigative journalism in the age of 'big data'. Digital Journalism, 3(3), 364-380. http://dx.doi.org/10.1080/21670811.2014.976408

Park, J., Baek, Y. M., \& Cha, M. (2014). Cross-cultural comparison of nonverbal cues in emoticons on Twitter: Evidence from big data analysis. Journal of Communication, 64(2), 333-354. https://doi.org/10.1111/ jcom. 12086

Pentzold, C., Brantner, C., \& Fölsche, L. (2019). Imagining big data: Illustrations of 'big data' in US news articles, 2010-2016. New Media \& Society, 21(1), 139-167. https://doi.org/10.1177/1461444818791326

Poel, M., Meyer, E. T., \& Schroeder, R. (2018). Big data for policymaking: Great expectations, but with limited progress? Policy and Internet, 10(3), 347-367. https://doi.org/10.1002/poi3.176

Puschmann, C., \& Burgess, J. (2014). Metaphors of big data. International Journal of Communication, 8, 16901709.

Qiu, J. L. (2015). Reflections on big data: 'Just because it is accessible does not make it ethical'. Media, Culture \& Society, 37(7), 1089-1094. https://doi.org/10.1177/0163443715594104

Quan-Haase, A., \& Sloan, L. (2017). Introduction to the handbook of social media research methods: Goals, challenges and innovations. In L. Sloan \& A. Quan-Haase (Eds.), The SAGE Handbook of Social Media Research Methods (pp. 1-9). London: SAGE Publications.

Rubin, V. L. (2017). Deception detection and rumor debunking for social media. In L. Sloan \& A. Quan-Haase (Eds.), The SAGE Handbook of Social Media Research Methods (pp. 342-363). London: SAGE Publications.

Sandoval-Martin, D., \& La-Rosa, L. (2018). Big data as a differentiating sociocultural element of data journalism: the perception of data journalist and experts. Communication \& Society, 31(4), 193-209. https://doi. org/10.15581/003.31.4.193-208

Schreier, M. (2014). Qualitative content analysis. In U. Flick (Ed.), The SAGE Handbook of Qualitative Data Analysis (pp. 170-183). Thousand Oaks, CA: SAGE Publications.

Shin, D. -H. (2015). Demystifying big data: Anatomy of big data developmental process. Telecommunications Policy, 40, 837--854. http://dx.doi.org/10.1016/j.telpol.2015.03.007

Statista (2020, January 10). Forecast of big data market size, based on revenue, from 2011 to 2027. Retrieved from https://www.statista.com/statistics/254266/global-big-data-market-forecast/ 
Stockmann, D. (2018). Toward area-smart data science: Critical questions for working with big data from China. Policy \& Internet, 10(4), 393--414. https://doi.org/10.1002/poi3.192

Tandoc Jr., E. C., \& Oh, S. K. (2017). Small departures, big continuities? Journalism Studies, 18(8), $997-1015$. https://doi.org/10.1080/1461670X.2015.1104260

Thatcher, J. (2014). Living on fumes: Digital footprints, data fumes, and the limitations of spatial big data. International Journal of Communication, 8, 1765-1783.

Vargo, C. J., \& Guo, L. (2017). Networks, big data, and intermedia agenda setting: An analysis of traditional, partisan, and emerging online U.S. news. Journalism \& Mass Communication Quarterly, 94(4), 1031-1055. https://doi.org/10.1177/1077699016679976

Vargo, C. J., Guo, L., \& Amazeen, M. A. (2018). The agenda-setting power of fake news: A big data analysis of the online media landscape from 2014 to 2016. New Media \& Society, 20(5), 2028-2049. https://doi. org/10.1177/1461444817712086

Veglis, A., \& Maniou, T. A. (2018). The mediated data model of communication flow: Big data and data journalism. KOME - An International Journal of Pure Communication Inquiry, 6(2), 32-43. http://doi.org/10.17646/ KOME.2018.23

Willson M., \& Leaver, T. (2015). Zynga's farmville, social games, and the ethics of big data mining. Communication Research and Practice, 1(2), 147-158. https://doi.org/10.1080/22041451.2015.1048039

Yang, F. (2016). Storytelling in the age of big data: Hong Kong students' readiness and attitude towards data journalism. Asia Pacific Media Educator, 26(2), 148-162. https://doi.org/10.1177/1326365X16673168

Yeh, C. -L. (2018). Pursuing consumer empowerment in the age of big data: A comprehensive regulatory framework for data brokers. Telecomunications Policy, 42(4), 282-292. https://doi.org/10.1016/j. telpol.2017.12.001

Zhang, Y., \& Wildemuth, B. M. (2009). Qualitative analysis of content. In B. Wildemuth (Ed.), Applications of social research methods to questions in information and library science (pp. 308-319). Westport, CT: Libraries Unlimited.

Zimmer, M. (2018). Addressing conceptual gaps in big data research ethics: An application of contextual integrity. Social Media + Society, 4(2), 1-11. https://doi.org/10.1177/2056305118768300 


\section{TABLOLAR VE ŞEKILLER}

Şekil 1: Araştırma Örneklemine Dâhil Edilen Makalelerin Yıllara Göre Dağılımı
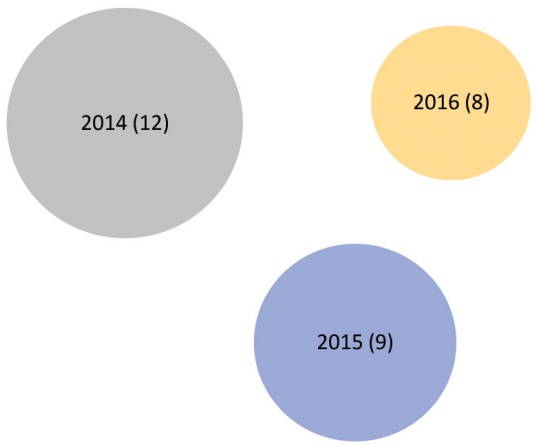

Şekil 2: Makalelerin Anahtar Kavramları ve Büyük Veriyle İlişkilendirilme Sıklığı

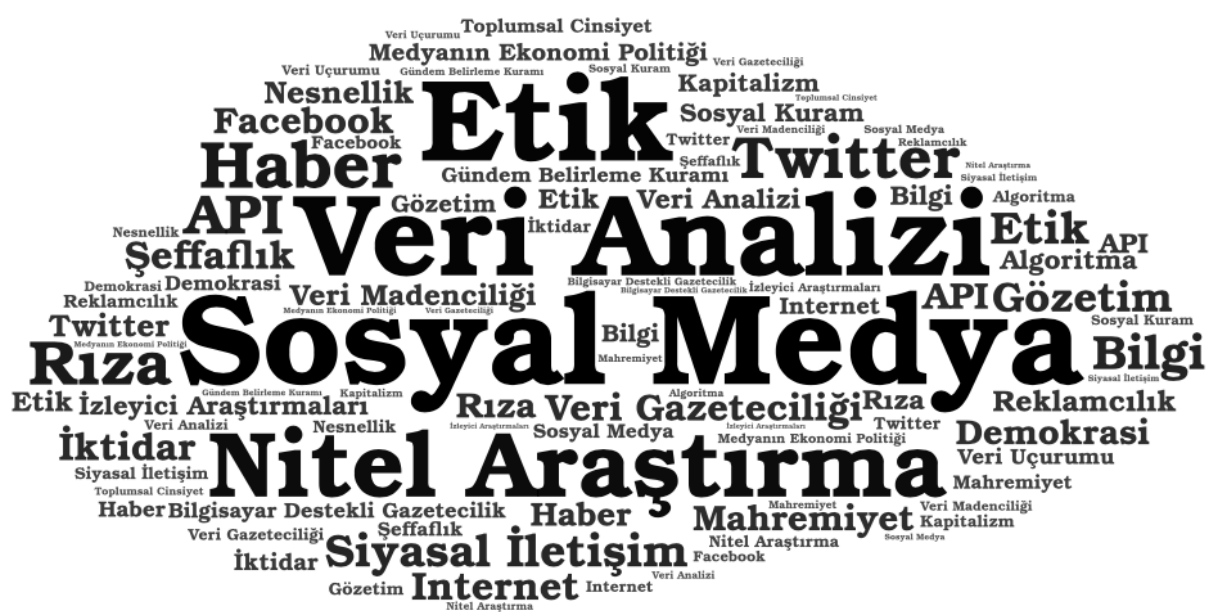


Şekil 3: Araştırma Örneklemine Dâhil Edilen Makalelerin Kategorik Farklılaşması

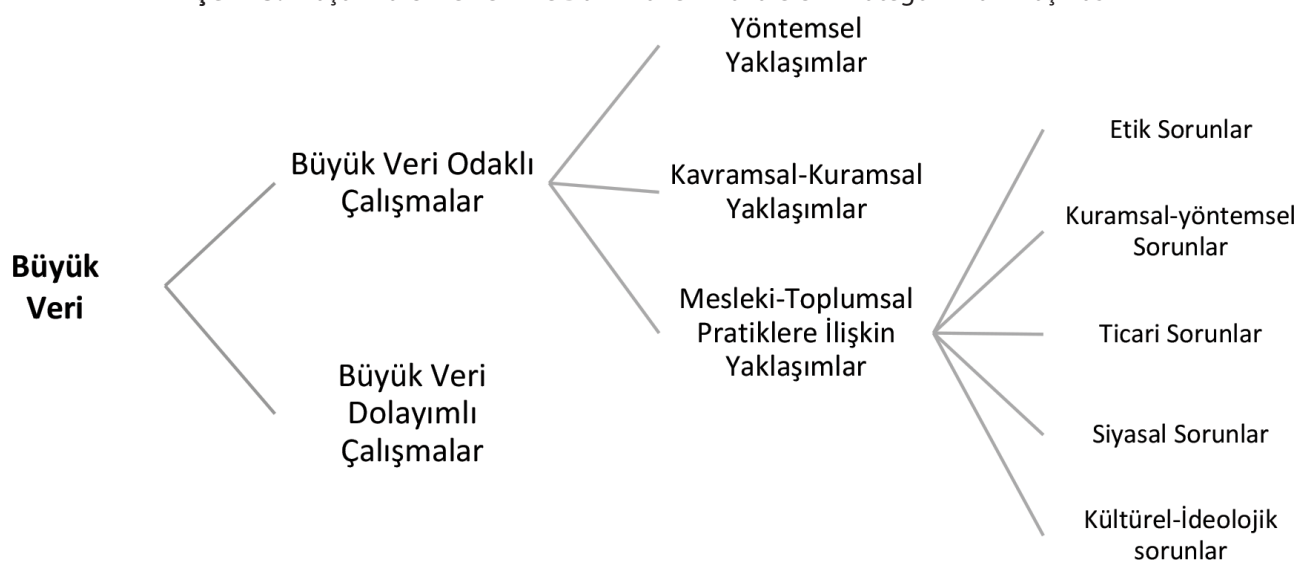


Tablo 1: Büyük Veri Dolayımlı Çalışmalara İlişkin Bulgular

\begin{tabular}{|c|c|c|c|c|c|c|}
\hline $\begin{array}{l}\text { Yazar ve } \\
\text { Tarih }\end{array}$ & $\begin{array}{c}\text { Araştırma } \\
\text { Konusu-Alanı }\end{array}$ & $\begin{array}{l}\text { Kuramsal } \\
\text { Çerçeve }\end{array}$ & $\begin{array}{l}\text { Araştırma } \\
\text { Yöntemi }\end{array}$ & Araç-Mecra & Veri & Temel Bulgular \\
\hline $\begin{array}{l}\text { Vargo, \& Guo, } \\
2017\end{array}$ & $\begin{array}{l}\text { Medya ve } \\
\text { gündem } \\
\text { belirleme }\end{array}$ & $\begin{array}{l}\text { Ağ gündem } \\
\text { belirleme } \\
\text { kuramı }\end{array}$ & $\begin{array}{l}\text { Çoklu nicel } \\
\text { yöntem }\end{array}$ & $\begin{array}{l}\text { Haber web } \\
\text { sayfaları }\end{array}$ & \begin{tabular}{|}
2.760 haber \\
sitesi, 48 \\
milyon \\
haber
\end{tabular} & $\begin{array}{c}\text { Büyük kurumsal } \\
\text { gazeteler haber } \\
\text { akışında artık kontrol } \\
\text { sahibi değillerdir. } \\
\text { Haber kuruluşları } \\
\text { birbirlerinin } \\
\text { gündemlerini } \\
\text { değişen ölçülerde } \\
\text { belirlemektedir. } \\
\text { Çevrimiçi } \\
\text { partizan haber } \\
\text { siteleri gündem } \\
\text { belirlemede etkin rol } \\
\text { oynamaktadır. }\end{array}$ \\
\hline $\begin{array}{l}\text { Neuman et } \\
\text { al., } 2014\end{array}$ & $\begin{array}{l}\text { Medya ve } \\
\text { gündem } \\
\text { belirleme }\end{array}$ & $\begin{array}{l}\text { Gündem } \\
\text { belirleme } \\
\text { kuramı }\end{array}$ & $\begin{array}{c}\text { Nicel } \\
\text { yöntem }\end{array}$ & $\begin{array}{l}\text { Twitter, } \\
\text { televizyon, } \\
\text { radyo, } \\
\text { gazete, } \\
\text { bloglar, } \\
\text { tartışma } \\
\text { forumları }\end{array}$ & $\begin{array}{c}3 \text { milyon } 650 \\
\text { bin tweet, } 1 \\
\text { milyon } 825 \\
\text { bin haber, } \\
219 \text { bin blog } \\
\text { mesajı, } 730 \\
\text { bin forum } \\
\text { yazısı }\end{array}$ & $\begin{array}{c}\text { Günümüzde } \\
\text { gündem belirleme } \\
\text { medyadan izleyiciye } \\
\text { çizgisel ve tek } \\
\text { yönlü değildir. } \\
\text { Sosyal medya } \\
\text { platformlarının, } \\
\text { tartışma forumlarının } \\
\text { ve blogların yaygın } \\
\text { olduğu bir yapı } \\
\text { içerisinde karmaşık } \\
\text { ve dinamik bir } \\
\text { etkileşim halini } \\
\text { almıştır. }\end{array}$ \\
\hline $\begin{array}{l}\text { Guo, \& Vargo, } \\
2017\end{array}$ & $\begin{array}{l}\text { Medya ve } \\
\text { gündem } \\
\text { belirleme }\end{array}$ & $\begin{array}{c}\text { Çoklu kuramsal } \\
\text { yaklaşım }\end{array}$ & $\begin{array}{c}\text { Çoklu nicel } \\
\text { yöntem ve } \\
\text { Ağ analiz } \\
\text { yöntemi }\end{array}$ & $\begin{array}{l}\text { Haber web } \\
\text { sayfaları }\end{array}$ & $\begin{array}{c}4 \text { bin } 708 \\
\text { haber sitesi, } \\
54 \text { milyon } \\
\text { haber }\end{array}$ & $\begin{array}{c}\text { Haber akışında } \\
\text { dengesizlik gelişmiş } \\
\text { ülkeler lehine } \\
\text { devam etmektedir. } \\
\text { Ancak merkezde } \\
\text { artık sadece ABD } \\
\text { bulunmamaktadır. } \\
\text { Gelişmiş ülkeler } \\
\text { az gelişmiş ülke } \\
\text { medyalarının } \\
\text { gündemini } \\
\text { belirlemeye devam } \\
\text { etmekte, kimi zaman } \\
\text { bunun tersi de } \\
\text { olabilmektedir. }\end{array}$ \\
\hline $\begin{array}{l}\text { Vargo, Guo, } \\
\text { \& Amazeen, } \\
2018\end{array}$ & $\begin{array}{l}\text { Medya ve } \\
\text { gündem } \\
\text { belirleme }\end{array}$ & $\begin{array}{l}\text { Gündem } \\
\text { belirleme } \\
\text { kuramı }\end{array}$ & $\begin{array}{l}\text { Nicel } \\
\text { yöntem }\end{array}$ & $\begin{array}{c}\text { Haber web } \\
\text { sayfaları }\end{array}$ & \begin{tabular}{|}
2.811 haber \\
sitesi, 42 \\
milyona \\
haber
\end{tabular} & $\begin{array}{l}\text { Yalan haberlerin } \\
\text { sayısı her gün } \\
\text { artmaktadır. Buna } \\
\text { karşın, yalan haberler } \\
\text { gündemi belirleme } \\
\text { gücüne sahip } \\
\text { değildir. }\end{array}$ \\
\hline
\end{tabular}




\begin{tabular}{|c|c|c|c|c|c|c|}
\hline $\begin{array}{l}\text { Kosterich, } \\
2016\end{array}$ & $\begin{array}{c}\text { İzleyici } \\
\text { araştırmaları/ } \\
\text { ölçümleri }\end{array}$ & $\begin{array}{c}\text { Çoklu kuramsal } \\
\text { yaklaşım }\end{array}$ & $\begin{array}{c}\text { Nicel } \\
\text { yöntem }\end{array}$ & \begin{tabular}{|c|} 
Özel şirket \\
(Nielsen \\
ölçüm şirketi)
\end{tabular} & $\begin{array}{c}1.040 \mathrm{TV} \\
\text { program } \\
\text { kesiti }\end{array}$ & \begin{tabular}{|c|} 
Reyting \\
ölçümlerindeki \\
değişiklik program \\
içeriklerine etki \\
etmektedir. \\
Sosyal medya \\
kullanıcılarının tercih \\
ettikleri programlar \\
geleneksel \\
izleyicilerin tercih \\
ettiklerine göre tür, \\
kaynak çeşitliliği \\
ve performans \\
açısından farklılık \\
göstermektedir.
\end{tabular} \\
\hline Feng, 2019 & $\begin{array}{c}\text { İzleyici } \\
\text { araştırmaları/ } \\
\text { ölçümleri }\end{array}$ & $\begin{array}{c}\text { Çoklu kuramsal } \\
\text { yaklaşım }\end{array}$ & $\begin{array}{c}\text { Çoklu nicel } \\
\text { yöntemi }\end{array}$ & $\begin{array}{l}\text { IMDb, } \\
\text { Douban }\end{array}$ & 25.708 film & $\begin{array}{c}\text { Filmin uyarlama } \\
\text { olup olmadığı, } \\
\text { bütçesi ve başrol } \\
\text { oyuncusu reytingi } \\
\text { etkileyen faktörlerdir. } \\
\text { Box Office başarısı } \\
\text { reytingler üzerinde } \\
\text { etki etmemektedir. }\end{array}$ \\
\hline $\begin{array}{l}\text { Nelson, \& } \\
\text { Webster, } \\
2016\end{array}$ & $\begin{array}{c}\text { İzleyici } \\
\text { araştırmaları/ } \\
\text { ölçümleri }\end{array}$ & $\begin{array}{c}\text { Çifte risk etkisi } \\
\text { kuramı }\end{array}$ & $\begin{array}{c}\text { Nicel } \\
\text { yöntem }\end{array}$ & $\begin{array}{l}\text { Haber web } \\
\text { sayfaları }\end{array}$ & $\begin{array}{l}861 \text { haber } \\
\text { sitesi ve } \\
\text { bu sitedeki } \\
\text { kullanıcı } \\
\text { etkileşimleri }\end{array}$ & $\begin{array}{c}\text { Markanın } \\
\text { tanınırlığının o } \\
\text { markaya ait ürünlerin } \\
\text { tüketimi üzerinde } \\
\text { mutlak olumlu etkisi } \\
\text { bulunmamaktadır. } \\
\text { Kullanıcılar, kimi } \\
\text { zaman bilinen } \\
\text { kimi zamanda } \\
\text { az bilinen haber } \\
\text { sitelerinde daha fazla } \\
\text { kalabilmektedirler. }\end{array}$ \\
\hline $\begin{array}{l}\text { Hokka, \& } \\
\text { Nelimarkka, } \\
2019\end{array}$ & Siyasal iletişim & $\begin{array}{l}\text { Duygulanımsal } \\
\text { ekonomi } \\
\text { kuramı }\end{array}$ & $\begin{array}{l}\text { Nicel } \\
\text { ve Nitel } \\
\text { yöntem }\end{array}$ & Facebook & $\begin{array}{c}8.000 \text { görsel, } \\
55.000 \\
\text { kullanıcı } \\
\text { yorumu }\end{array}$ & $\begin{array}{l}\text { Sosyal ağlarda } \\
\text { görsel paylaşım, } \\
\text { yorum ve diğer } \\
\text { tepkiler kullanınılar } \\
\text { arasında sürekliliği } \\
\text { olan bir etkileşim } \\
\text { üretmektedir. } \\
\text { Kullanıcılar bu } \\
\text { etkileşim içinde } \\
\text { kendi politik } \\
\text { kimliklerini, } \\
\text { duygularını ve } \\
\text { aidiyetlerini } \\
\text { paylaşmaktadırlar. } \\
\text { Bunlar, paylaşılan } \\
\text { görsellere } \\
\text { duygulanımsal bir } \\
\text { değer katmaktadır. }\end{array}$ \\
\hline
\end{tabular}




\begin{tabular}{|c|c|c|c|c|c|c|}
\hline $\begin{array}{l}\text { Guo, \& Vargo, } \\
2015\end{array}$ & $\begin{array}{c}\text { Siyasal } \\
\text { iletişim, } \\
\text { siyasal } \\
\text { kampanyalar }\end{array}$ & $\begin{array}{l}\text { Ağ gündem } \\
\text { belirleme } \\
\text { kuramı }\end{array}$ & $\begin{array}{l}\text { Çoklu nicel } \\
\text { yöntem } \\
\text { ve Sosyal } \\
\text { ağ analiz } \\
\text { yöntemi }\end{array}$ & Twitter & $\begin{array}{l}70 \text { milyon } \\
\text { tweet }\end{array}$ & $\begin{array}{c}\text { Haber medyası } \\
\text { seçmenin siyasi } \\
\text { parti adaylarını } \\
\text { hangi konularla } \\
\text { özdeşleştirip } \\
\text { tanımladığı üzerinde } \\
\text { etkilidir. Geleneksel } \\
\text { medya hala gündem } \\
\text { belirlemede etkili bir } \\
\text { araçtı. Siyasal seçim } \\
\text { kampanyaları, haber } \\
\text { medyasına göre } \\
\text { daha az etkili olsa } \\
\text { da seçmenin siyasi } \\
\text { parti adaylarını nasıl } \\
\text { tanımladığı üzerinde } \\
\text { etkilidir. }\end{array}$ \\
\hline $\begin{array}{l}\text { Konitzer et } \\
\text { al., } 2019\end{array}$ & $\begin{array}{c}\text { Siyasal } \\
\text { iletişim, } \\
\text { siyasal } \\
\text { kampanyalar, } \\
\text { reklamcılık }\end{array}$ & - & $\begin{array}{c}\text { Nicel } \\
\text { yöntem }\end{array}$ & $\begin{array}{l}\text { Televizyon, } \\
\text { Twitter }\end{array}$ & $\begin{array}{l}346.000 \\
\text { kişiden } \\
\text { elde edilen } \\
\text { görüssme } \\
\text { verileri, } \\
45 \text { gün } \\
\text { boyunca } \\
\text { yayınlanan } \\
\text { TV } \\
\text { reklamları, } \\
495.000 \\
\text { tweet }\end{array}$ & $\begin{array}{l}\text { Daha fazla TV reklamı } \\
\text { adaylar için daha } \\
\text { fazla yarar anlamına } \\
\text { gelmemektedir. } \\
\text { Toplam reklam } \\
\text { harcamalarındaki } \\
\text { artış, adaylara yarar } \\
\text { sağlamamaktadır. } \\
\text { Reklam } \\
\text { harcamalarında } \\
\text { yükseliş oy verme } \\
\text { davranış üzerinde } \\
\text { negatif bir etkiye } \\
\text { dönüşmektedir. } \\
\text { Reklam harcamaları, } \\
\text { kullanıııların } \\
\text { adaylarla ilgili tweet } \\
\text { pratiğinde olumlu bir } \\
\text { etkiye sahiptir. }\end{array}$ \\
\hline $\begin{array}{l}\text { Colleoni, } \\
\text { Rozza, \& } \\
\text { Arvidson, } \\
2014\end{array}$ & $\begin{array}{c}\text { Siyasal } \\
\text { iletişim, } \\
\text { kamusal alan, } \\
\text { kamusal } \\
\text { tartışmalar. }\end{array}$ & $\begin{array}{c}\text { Kamusal alan } \\
\text { kuramı }\end{array}$ & $\begin{array}{c}\text { Sosyal } \\
\text { ağ analiz } \\
\text { yöntemi }\end{array}$ & Twitter & $\begin{array}{l}218.000 \\
\text { tweet }\end{array}$ & $\begin{array}{c}\text { Twitter sosyal } \\
\text { ağ olarak aynı } \\
\text { fikirden insanların } \\
\text { etkileşimine olanak } \\
\text { tanımakta bu yolla } \\
\text { 'yankı odası' etkisine } \\
\text { neden olmaktadır. } \\
\text { Twitter bir haber } \\
\text { mecrası olarak } \\
\text { kamusal tartışmalara } \\
\text { katkı sunmaktadır. }\end{array}$ \\
\hline
\end{tabular}




\begin{tabular}{|c|c|c|c|c|c|c|}
\hline $\begin{array}{l}\text { Kim et al., } \\
2016\end{array}$ & $\begin{array}{c}\text { Kamusal } \\
\text { alan, kamusal } \\
\text { tartışmalar }\end{array}$ & $\begin{array}{l}\text { Gündem } \\
\text { belirleme } \\
\text { kuramı }\end{array}$ & $\begin{array}{c}\text { Nicel } \\
\text { ve Nitel } \\
\text { yöntem }\end{array}$ & Twitter & $\begin{array}{l}30 \text { milyon } \\
\text { tweet }\end{array}$ & $\begin{array}{c}\text { Atılan tweetler } \\
\text { çoğunlukla } \\
\text { geleneksel medyanın } \\
\text { haber linkini } \\
\text { içermektedir. Bu, } \\
\text { geleneksel medyanın } \\
\text { Twitter gündemini } \\
\text { belirleyebildiğini } \\
\text { göstermektedir. Öte } \\
\text { yandan bir olayla } \\
\text { ilişkili tweetler } \\
\text { olayın niteliğine } \\
\text { göre farklı ruh halini } \\
\text { yansıtmaktadır. } \\
\text { Örneğin kötü bir olay } \\
\text { olduğunda tweetler } \\
\text { kötümser içerikte } \\
\text { olabilmektedir. }\end{array}$ \\
\hline $\begin{array}{l}\text { Park, Baek, \& } \\
\text { Cha, } 2014\end{array}$ & $\begin{array}{l}\text { Bilgisayar } \\
\text { destekli } \\
\text { iletişim }\end{array}$ & $\begin{array}{c}\text { Kültürel } \\
\text { farklılıklar } \\
\text { kuramı }\end{array}$ & $\begin{array}{c}\text { Çoklu nicel } \\
\text { yöntem }\end{array}$ & Twitter & $\begin{array}{c}55 \text { milyon } \\
\text { kullanıcı, } 1,7 \\
\text { milyar tweet }\end{array}$ & $\begin{array}{l}\text { Kültürel farklılık, } \\
\text { sözsüz iletişimde } \\
\text { farklılığa neden } \\
\text { olmaktadır. Örneğin, } \\
\text { bireyci kültürün } \\
\text { egemen olduğu ülke } \\
\text { kullanıcıları yatay ve } \\
\text { ağız temelli (gülen } \\
\text { surat), ortaklaşmacı } \\
\text { kültürün baskın } \\
\text { olduğu ülke } \\
\text { kullanıcıları dikey ve } \\
\text { göz temelli emojiler } \\
\text { kullanmaktadır. }\end{array}$ \\
\hline $\begin{array}{l}\text { Carpenter, \& } \\
\text { Amaravadi, } \\
2019\end{array}$ & $\begin{array}{l}\text { Bilgisayar } \\
\text { destekli } \\
\text { iletişim }\end{array}$ & $\begin{array}{c}\text { Toplumsal } \\
\text { normlar kuramı }\end{array}$ & $\begin{array}{c}\text { Nicel } \\
\text { yöntem }\end{array}$ & $\begin{array}{l}\text { EveryMove } \\
\text { mobil } \\
\text { uygulaması }\end{array}$ & $\begin{array}{c}67.900 \\
\text { kullanıcı } \\
\text { içeriği }\end{array}$ & $\begin{array}{l}\text { Sosyal ağlarda diğer } \\
\text { kullanıılarca üretilen } \\
\text { ortalama içerik ve } \\
\text { sahip olunan arkadaş } \\
\text { sayısı bir kullanııının } \\
\text { ürettiği içerik } \\
\text { miktarı üzerinde bir } \\
\text { etkiye sahiptir. Bu, } \\
\text { toplumsal normların } \\
\text { bireylerin iletişimsel } \\
\text { davranışları üzerinde } \\
\text { etkili olabildiğini } \\
\text { göstermektedir. }\end{array}$ \\
\hline
\end{tabular}




\begin{tabular}{|c|c|c|c|c|c|c|}
\hline $\begin{array}{l}\text { Pentzold, } \\
\text { Brantner, \& } \\
\text { Fölsche, } 2019\end{array}$ & $\begin{array}{l}\text { Temsil, } \\
\text { Söylem }\end{array}$ & - & $\begin{array}{c}\text { Nicel } \\
\text { ve Nitel } \\
\text { yöntem }\end{array}$ & Gazeteler & $\begin{array}{l}450 \text { gazete } \\
\text { görseli }\end{array}$ & \begin{tabular}{|c|} 
Gazeteler soyut olan \\
veriyi somutlaştırarak \\
görselleştirmektedir. \\
Öte yandan, büyük \\
veri görselleri \\
olumlu, olumsuz \\
ve yansız olarak \\
sunulmaktadır. \\
Ayrıca, büyük veri \\
erkek görselleri \\
eşliğinde \\
çerçevelenmektedir.
\end{tabular} \\
\hline $\begin{array}{l}\text { Tandoc Jr., \& } \\
\text { Oh, } 2017\end{array}$ & $\begin{array}{l}\text { Gazetecilik } \\
\text { pratikleri }\end{array}$ & - & $\begin{array}{c}\text { Nicel } \\
\text { yöntem }\end{array}$ & Gazeteler & 2.660 haber & $\begin{array}{l}\text { Büyük veri olgusu } \\
\text { gazetecileri yeni } \\
\text { kaynaklar bulmaya } \\
\text { zorlamaktadır. } \\
\text { Buna karşın, } \\
\text { veri gazeteciliği } \\
\text { haberlerinde } \\
\text { gazeteciler } \\
\text { geleneksel } \\
\text { gazetecilik } \\
\text { pratiklerini } \\
\text { sürdürmeye devam } \\
\text { etmektedirler. }\end{array}$ \\
\hline $\begin{array}{l}\text { Margolin, \& } \\
\text { Markowitz, } \\
2018\end{array}$ & Dilbilim & $\begin{array}{c}\text { Çoklu kuramsal } \\
\text { yaklaşım }\end{array}$ & $\begin{array}{c}\text { Dilbilimsel } \\
\text { analiz } \\
\text { yöntemi }\end{array}$ & $\begin{array}{l}\text { Yelp forum } \\
\text { sitesi }\end{array}$ & $\begin{array}{l}300.000 \\
\text { kullanıcı } \\
\text { yorumu }\end{array}$ & $\begin{array}{c}\text { Kullanılan dilin biçimi } \\
\text { düşüncenin içeriğini } \\
\text { belirleyebilmektedir. } \\
\text { Anlatımsal- } \\
\text { dokunaklı biçimler } \\
\text { pozitif duygular, } \\
\text { retoriksel biçimler } \\
\text { negatifler duygular } \\
\text { içermektedir. Illk } \\
\text { biçim, ikincisine } \\
\text { göre daha fazla } \\
\text { kullanıc tarafından } \\
\text { desteklenmektedir. }\end{array}$ \\
\hline
\end{tabular}

